University of Michigan Law School

University of Michigan Law School Scholarship Repository

\title{
The Development of Modern Corporate Governance in China and India
}

\author{
Nicholas C. Howson \\ University of Michigan Law School, nhowson@umich.edu
}

Vikramaditya S. Khanna

University of Michigan Law School, vskhanna@umich.edu

Available at: https://repository.law.umich.edu/book_chapters/66

Follow this and additional works at: https://repository.law.umich.edu/book_chapters

Part of the Business Organizations Law Commons, and the Comparative and Foreign Law Commons

\section{Publication Information \& Recommended Citation}

Howson, Nicholas C. "The Development of Modern Corporate Governance in China and India." V. S. Khanna, co-author. In China, India and the International Economic Order, edited by M. Sornarajah and J. Wang, 513-76. Cambridge: Cambridge Univ. Press, 2010.

This Book Chapter is brought to you for free and open access by the Faculty Scholarship at University of Michigan Law School Scholarship Repository. It has been accepted for inclusion in Book Chapters by an authorized administrator of University of Michigan Law School Scholarship Repository. For more information, please contact mlaw.repository@umich.edu. 


\title{
The development of modern corporate governance in China and India
}

\author{
NICHOLAS CALCINA HOWSON \\ AND VIKRAMADITYA S.KHANNA
}

\section{Introduction}

Corporate governance reform has become a topic of considerable debate both in the US and in many emerging markets. Indeed, the discussion is important because these reforms may have potentially long-standing effects upon the global allocation of capital, and in understanding the ways in which governance norms are communicated across markets and nations in an ever-globalizing world. In this chapter we examine the corporate governance reform efforts of the world's two biggest and fastest growing emerging markets, the People's Republic of China (PRC or China) and India. In the process we find that our understanding of how and why corporate governance reform comes about, where it leads, and what value it has can vary significantly, but still shares some commonalities that are of considerable theoretical and practical importance.

The inquiry commenced in this chapter is inspired by certain key facts. First, China and India are growing at a remarkable and unprecedented pace and seem to have survived the 2008-9 Global Financial Crisis better than most other economies. Second, China and India are not Western countries, but have been heavily influenced by "globalized" Anglo-American notions of corporate law, corporate governance norms, and securities regulation. Third, China and India are presently two of the most popular destinations for foreign capital in the world whether via foreign direct investment (FDI) in essentially private (or pre-public) transactions or public capital markets transactions. Fourth, both India and China have undergone, and are progressing through, incredibly important (indeed world-changing) programs of economic reform and restructuring. At the same time they are increasingly in the Chinese phrase - "opening to the outside world." These are 
the shared "facts" of our inquiry, which of course are met by many deep differences, in particular relating to the history, internal organization and political and economic structures of the two great nationcivilizations. However, we believe that the common "facts" recited above - rapid economic development, significant private and public foreign investment, economic, structural and legal/regulatory reform, speedy recovery from the Global Financial Crisis, and a shared interest in (if not implementation of) in essentially Anglo-American corporate law norms - provide an interesting and rich platform for consideration of popular or contested corporate governance and corporate governance reform precepts.

To engage in this exploration, we approach the task in several sections. Section II provides the background for examining the development of corporate governance reform in China and India. We examine in skeletal form the political, economic, legal and other features animating the environments in both countries. Section III examines the development of modern corporate governance reform in India which, unlike many other emerging markets, was largely initiated by industry (rather than being, for example, scandal driven). Section IV begins with detailed discussion of the modern effort at corporate business organization in China, and the program of reform applied to the corporate governance implemented subsequently. In particular, we examine how the advent of "corporatization" (a strategy to finance underperforming state-owned enterprises (SOEs)), along with certain central government agencies and reform-oriented individuals in China, helped further the development and reform of modern Chinese corporate governance. Section V explores what the Indian and Chinese experiences can tell us about broader theoretical issues animating the corporate governance literature. In particular, we examine what we can learn about the impact of "legal origins" (common law or civil law) as compared to "politics" on the development of stock markets in the two countries. In addition, we discuss whether India and China provide evidence for some kind of convergence in corporate law. We find that the support for the "legal origins" view is not strong, but that the "politics" account seems more relevant in explaining stock market development in India and China. Further, while there is a good deal of evidence of partial formal convergence in corporate law, we cannot identify the same or expected convergence in ownership or corporate structure. This creates an odd fit between corporate and securities law and the corporations they shape and regulate, suggesting some path dependence. Section VI concludes. 


\section{Background environments in China and India}

Before discussing the development of corporate governance reform in China and India it seems useful to provide some context for the discussion. Although there is presently great enthusiasm about the prospects for both countries, it is important to note the similarities and differences between them.

In terms of similarities, both countries are geographically vast with very large populations. ${ }^{1}$ They both also have huge urban populations, but still sizeable rural areas. Further, China and India possess large and highly successful diasporas throughout the world, which are involved in varying degrees with the growth and success in their countries of origin. Moreover, both countries started their lives in modern times as postcolonial independent or newly autonomous nations at roughly the same time (1947 and 1949), with both initially adopting less market-oriented policies. Nevertheless, over the last three decades both countries have implemented market-oriented reforms that have led to phenomenal growth rates and nearly geometric expansion in international trade connections and access to global capital markets. Indeed, they have become the most attractive destinations for foreign direct investment, and now routinely record the world's largest initial public offerings and capital markets corporate finance transactions. Finally, although both countries are generating significant growth, they are still plagued by some of the familiar problems of emerging markets: slow (and sometimes ill-prepared and politically compromised) judiciaries, corruption at various levels, and acute infrastructure problems (e.g., electricity, roads).

This, however, is where most of the similarities end. In terms of political structure the two countries are quite different. ${ }^{2}$ India is a functioning democracy with many political parties and active elections, whereas China remains a one Party state, whereby the state is ruled absolutely by the Communist Party of China. ${ }^{3}$ In addition to this,

${ }^{1}$ Many of the facts noted in this paragraph come from a variety of sources. See, e.g.: Yasheng Huang and Tarun Khanna, "Can India overtake China?" Foreign Policy, JulyAugust 2003; The Economist (2006); and Business Week (2005) (article on China-India).

2 Huang and Khanna, "Can India overtake China?".

${ }^{3}$ China's political and governance structure is theoretically divided between: the Party (under the Politburo), the state (under the executive (State Council and its ministries)), the legislature (the National People's Congress) and the military (the People's Liberation Army, under the Central Military Commission, the Chairman of which is a Party appointee). The state (executive and legislature) and military are in fact controlled by the Party through Party appointments to what appear to be state or military institutions. 
although both countries have populations including different groups of people, the heterogeneity in India is quite broad relative to that in China. There are many official languages in India (over 20), no clear majority group (except arguably "Hindus"), and the presence of parallel legal systems operating simultaneously throughout the country. These factors simply underscore the heterogeneity reflected in India's population. The population's heterogeneity, absence of a clear majority group, and democracy in India mean that it is considerably more difficult to pass orders from the "top" and expect them to be followed at the grass roots. Indeed, India's policies have tended to flow from the grass roots upwards. While China proclaims its more than 50 "national minorities," it is a far more homogeneous polity in ethnic and language terms. China's political and institutional culture is a work in progress, and certainly the significant contest between central and regional (or local) authority has been exacerbated by the devolution of political and economic decision making in the Reform era. Notwithstanding, China is still formally a unitary state, and its governance and reform experience has long been more "top down" than that made necessary and possible by India's historical and political development. ${ }^{5}$

Nowhere are these political differences seen more than in the approach toward economic development and the financing of it. China commenced its domestic economic reforms concurrent with a financing strategy that focused on raising FDI - initially private foreign investment and in the last 15 years foreign equity participation in public capital markets. Only recently has it turned to domestic capital. India, on the other hand, began by attempting to develop local talent and only then focused on the attraction of FDI. This was not only a result of historical aversion in India to foreign investment post-colonization, but also

${ }^{4}$ When there is no clear majority in a democracy, coalitions become necessary. Moreover, when there are many different groups (i.e., high heterogeneity) one cannot simply ignore some groups because one may have to enter into coalitions with them later. This suggests more consensus-oriented decision-making.

5 Note, this is not to suggest that China has no need for consensus decision making - it is simply a relative statement compared to India. Moreover, China does have divisions: horizontally between the various regions in China, and vertically between the central and local levels. Many of these tensions have become exacerbated in recent years as different areas of China develop at radically different speeds, and the gap between rich and productive coastal (and in some cases interior) urban areas and the countryside widens. At this time, the central government is attempting to address this widening disparity, often relying upon a difficult-to-implement re-centralization to effect it. 
because consensus decision-making would have made it difficult to follow a path of simply encouraging foreign investment in India.

The result, at least at this point in history, is that while China's growth has outpaced India's there are few truly indigenous Chinese firms (and only a handful not built on a pre-existing SOE or local governmentpromoted enterprise) that are considered internationally competitive, whereas many completely indigenous and non-state owned Indian firms compete internationally in many of the highest growth fields (high tech, pharmaceuticals, biotech). Indeed, in the early stages of China's capital markets development, China placed restrictions on the ability of non-SOE firms to raise capital largely to reduce the competitive threat they would pose to China's then cash-hungry and increasingly corporatized SOEs. ${ }^{6}$

However, FDI is only one small part of the reform programs that both countries have put into effect. We simply note that both countries have moved away from the communist (China) or somewhat socialist (India) visions they possessed and toward more mixed market economies. China has in fact moved to a kind of "wild west" autocratic capitalism, where control and of ten ownership remain vested in state or state-tied actors, limited duopolies flourish, and the state does not provide any real social support for broader society.

In China this has involved, amongst other things, the "corporatization" process (described in greater detail in Section IV) wherein a number of SOEs are being, or have been, reorganized as corporations in law, but not privatized in any real sense. Although there were exceptions for sensitive areas (e.g., national security and major infrastructure or energy), most non-sensitive previously state owned assets have been devolved to local level government actors (which function at differing levels of entrepreneurialism) or into private, entrepreneurial, hands. The relations between the enterprises and other economic actors have become increasingly subject to a marketplace where prices are not controlled, and value-creating transactions (including finance transactions) are described and normatively enforced "under law."7

${ }^{6}$ Although the Chinese Communist Party has, since 1979, engaged in an aggressive program of economic reform, it has been far more cautious about anything that might relate to, or trigger, political reform.

7 Indeed, growth has been stimulated by local level enterprises (many originally permitted "collective" enterprises), foreign funded enterprises (which have been the lynchpin of China's export-led growth), and private enterprises (especially in "new" sectors where neither SOEs nor collectives were present, for example in the Internet-related sector). 
In India, SOEs are being privatized on a case-by-case basis. Although the process has been erratic at times, it appears to be on somewhat more solid footing now. The newly privatized entities have been revamped and some are considered very profitable and are market leaders. ${ }^{8}$

These reforms, among other factors, have led to tremendous growth in both countries. We will not rehearse the numbers here except to note that in most numerical categories China has outperformed India (e.g., gross domestic product (GDP) growth around $9 \%$ compared to $5 \%$ to $6 \%$ for India), but in the last few years the gap has narrowed considerably. ${ }^{9}$

Clearly, economic growth is important for both countries. In China, it may be most important, as it may be the last and only way that the Communist Party can maintain the support and affection of Chinese citizens. At the same time, there is a sense in which India's growth although by no means evenly distributed - is less skewed than China's. The broader base of growth in India implies somewhat greater political stability and support. In China if growth were to slow significantly then some fear that those who have not benefited from growth might react to weakening economic conditions and add to China's already roiling social discontent. This scenario only highlights how important sustained growth in China is - politically - for the Chinese Communist Party and its continuing hold on power. Good governance at the enterprise level, and the resulting efficiency gains, are thus of paramount importance in the political-economic calculations of China's leadership.

In light of the sheer speed of China's economic growth and its political importance, it seems surprising that China's stock markets languished for the five year period between 2000 and 2005, while India's boomed over the same period. One set of reasons for this difference, other than the structures of the respective financial sector, was the situation regarding corporate governance at the enterprise level and general rule of law concerns in China. Before briefly touching on those it is perhaps noteworthy that

${ }^{8}$ An example would be Industrial Credit and Investment Corporation of India (ICICI) Bank.

${ }^{9}$ For the past twenty-five years China has seen average annual GDP growth rates of more than 9\% (except for two years); since 1999, the PRC has seen steadily ascending percentage increases in GDP growth on the year earlier from 7.5\% (1999) to just under 10\% (2005). The economy has other strengths too: national revenue growth has averaged $18 \%$ since 1994, the current deficit is only $1.6 \%$ of GDP, and public debt is less than a quarter of GDP; and China currently has almost US\$850 billion in foreign exchange reserves, and one of the world's highest savings rates (approximately $40 \%$ of GDP). Much of the information contained in this paragraph is taken from James Miles' excellent China Survey in The Economist, 25 March 2006, p. 12. Also for greater comparative discussion of India and China see Huang and Khanna, "Can India overtake China?". 
India and China came at the problem of corporate governance from different perspectives. In India corporate governance reform was built on a pre-existing corporate landscape and started with the private sector and only later became an issue for the public sector as well, whereas in China it worked the other way round. ${ }^{10}$ This is not surprising given that in China there were initially few, if any, truly private enterprises with a large appetite for capital, only newly corporatized SOEs. Accordingly, corporate governance concerns in China focused first on what we might think of as public sector firms. Nonetheless, the starting point for corporate governance reform - although not surprising in each country - is likely to have important implications for the shape of how that reform occurred and is likely to proceed.

Having begun discussion of some corporate governance differences between the countries, we proceed now to briefly sketch out some other legal differences of note. ${ }^{11}$ Legislation in India is seen as being more transparent and shaped more by the rule of law than in China where there appears to be considerable opacity in determining who is drafting laws, with what degree of technical expertise, and in the service of what policies. Moreover, various state departments and agencies in China are able to issue regulations which often have greater specificity, and force, than "law" promulgated by the legislature. Additionally, in India, although the judiciary operates on a somewhat glacial time frame, it is considered more experienced with commercial matters. Chinese courts are generally considered less technically competent and not nearly as autonomous or politically independent as their Indian counterparts.

Some may attribute these distinctions to somewhat artificial assignments of legal system affiliation/origins: between common law (India) and civil law (China). We explore this issue more fully in sub-section V.A, but suffice to say for now that these labels are somewhat misleading. In particular, China's developing legal system is a more mixed bag of different legal systems and regimes than the obscuring "civil law" designation conveys. ${ }^{12}$

${ }^{10}$ Governance concerns emanated first from the SOEs and that is where most of the legislation has been. However, governance reform is now happening in China's foreign-funded enterprises, reformed collectives, and newly established private enterprises.

11 Huang and Khanna, "Can India overtake China?"

12 Many PRC scholars will articulate easy assurances that the PRC has established a "civil law" system (dalu faxi). Although one can examine why this view became common, we avoid that and instead simply note that China's modern, post-Reform, legal system was based on an imperfectly understood Stalinist Soviet system (itself channeling prior Alexandrine reforms from the nineteenth century). That system was attached to a prior tradition of law which has existed in China for more than 2,000 years (what Qu Tongzu 
With this background we now examine the development of corporate governance reform in India and in China. Although we have noted some differences between the countries, we want to re-emphasize that there remain many commonalities too - rapid economic development, significant private and public foreign investment, economic and structural reform, and a shared interest in (if not implementation of) Anglo-American corporate law norms - which we will argue provide an interesting and rich platform for consideration of popular or contested corporate governance and corporate governance reform precepts.

\section{The development of corporate governance in India}

The reform of corporate governance is a worldwide phenomenon. In the last decade India has engaged in an ambitious series of reforms. In order to better understand the context of these reforms, we briefly discuss the corporate governance situation in India prior to these reforms.

Modern corporate governance in India dates back to the later half of the 1800s under the British Raj. By the time of Independence in 1947 India had functioning stock markets and a comparatively well-developed model of corporate governance. Following Independence the Indian government pursued socialist policies that led to the growth of the state owned sector and a greater role for the state as the primary provider of debt and equity capital. The results included a decline in corporate governance. By 1991 the financial position of the Indian government was quite precarious. This led it to embark on a series of market oriented reforms involving a retraction of the state from the corporate sector and a general liberalization of the economy. By the mid 1990s Indian industry began to search for capital to expand into the competitive spaces being left open by the liberalization policies. The need for capital, amongst other things, led to the first forays into corporate governance reform in India starting with the Confederation of Indian Industry's

called "the Confucianization of Law"), and then a German-influenced system (mediated through Meiji Japan) implemented by the late Qing and then Guomindang Republican governments of the 1920s and 1930s. After 1979, and the advent of "legal construction," and always based on the pre-existing Soviet-inspired system, China has been subject to a number of strong influences, depending upon the specific sector of "law" implicated. For instance, in the corporate and securities law spheres, the influence of US-style corporate law and securities law - notwithstanding the adjacency of British law haven Hong Kong has been near overwhelming. This no doubt is a result of the pervasive influence of US ideas and structures communicated through the US-directed globalized capital markets. 
Code for Corporate Governance in 1998 which was quickly followed by the government enhancing corporate governance via listing requirements (in 2000) and amendments to the Company Law.

In many respects the saga of modern corporate governance in India is the story of the prodigal son - a promising start followed by a decline with much more recent attempts at enhancing governance. The details of how this happened are briefly described in the next few paragraphs.

\section{A. Origins of modern corporate governance in India (1866 to 1947)}

India, unlike a number of emerging markets, has had functioning stock markets since 1875 where much of the activity was organized in the form of joint-stock limited liability companies. In light of the early presence of corporations in India it is not surprising that the regulation of corporate governance started relatively early. From 1866 onwards there were many pieces of legislation governing corporate governance, trust activity, banking activity and securities regulation. ${ }^{13}$ Moreover, it appears that Indian industry grew considerably during World War II because the Chinese and Japanese economies, which were in some sense competitors, were damaged by the war and by wartime activities on their territories. ${ }^{14}$ Thus, by the time of Independence (1947), India appeared to have wellfunctioning stock markets, an active manufacturing sector, a large corpus of corporate and securities laws, and a well-developed banking

13 Amiya Kumar Bagchi, Private Investment in India, 1900-1939 (Cambridge University Press, 1972); Radhe Shyam Rungta, The Rise of usiness Corporations in India, 1851-190 (Cambridge University Press, 1970). See the Indian Companies Act 1866; Indian Companies Act 1882; Indian Trusts Act 1882; Indian Companies Act 1913; Reserve Bank of India Act 1934; 1956 Indian Companies Act (in the process of being re-written); 1956 Securities Contracts (Regulation) Act (defines powers and conduct for stock exchanges); 1985 Sick Industrial Companies (Special Provisions) Act (bankruptcy provisions for financially distressed companies - also being re-written); 1992 Securities and Exchange Bureau of India (SEBI) Act (sets up SEBI - regulator of stock markets). For more discussion of the growth of Indian Industry since the beginning of the twentieth century see M. D. Morris, "The growth of large scale industry up to 1947," in D. Kumar (ed.), Cambridge Economic History of India, vol. II (Cambridge University Press, 1983), pp. 553-676. Note that even prior to the 1866 Act there were corporations in India, primarily in the Bengal (Calcutta) area.

14 See Sir Purshotamdas Thakurdas, J. R. D. Tata, G. D. Birla, Sir Ardeshir Dalal, Sir Shri Ram, Kasturbhai Lalbhai, A. D. Shroff and John Matthai, The "Bombay Plan" for India's Economic Development (Bombay: Printed by S. Ramu, at the Commercial Printing Press, 1944). 
establishment. ${ }^{15}$ Although there were certainly corporate governance abuses, the general state of corporate governance and the overall economy in India placed it in an enviable position amongst many decolonized countries. ${ }^{16}$ This position was, however, about to receive some serious setbacks.

\section{B. From Independence to liberalization (1947 to 1991)}

Following Independence the Indian government put into place a number of policies that had the effect of weakening corporate governance in India. This started with a series of Industrial Policy Resolutions which entrusted the state with much greater responsibility for managing the economy. ${ }^{17}$ The changes wrought by these resolutions included a much expanded state-owned sector. ${ }^{18}$ The government was to become the sole provider of many goods and services. ${ }^{19}$ This led to the nationalization of certain industries (in particular financial institutions such as banks and insurance companies) and the removal of private firms and competition from large sectors of the economy. This would have reduced the competitive pressure to be efficient. Moreover, Indian SOEs were not simply

${ }^{15}$ Rajesh Chakrabarti, The Financial Sector in India: Emerging Issues (New Delhi; New York: Oxford University Press, 2006); Omkar Goswami, "India: The tide rises gradually," in Charles P. Oman (ed.), Corporate Governance in Development: The Experiences of Brazil, Chile, India, and South Africa (Issy-les-Moulineaux: OECD Development Center; Washington DC: Center for International Private Enterprise, 2003).

${ }^{16}$ Many corporations in India during this time frame were operated under the managing agent system. This provided an impetus to dispersed ownership and a separation of ownership from control. Although the use of the corporate law statutes helped to contain the agency costs that arose from this situation, it was hardly perfect and many instances of abuses by managing agents are documented in the modern business history of India. See Rungta, The Rise of Business Corporations, pp. 219-55.

17 Rakesh Mohan and Vandana Aggarwal, "Commands and controls: Planning for industrial development in India, 1951-1990" (1990) 14 Journal of Comparative Economics 681. Some of these changes bear considerable similarity to the suggestions laid out by the leading Indian Industrialists in the 1944 Bombay Plan. The Plan was to be a blueprint for economic growth in India and many of its suggestions seem to have been adopted by the first few Indian governments.

19 There were also some industries where only the state could start new firms. See Goswami, "India: The tide." There appeared to be a belief that the private sector, domestic and foreign, could not be relied upon to provide these goods and services and that they may have incentives that do not enhance social welfare. See Chakrabati, Financial Sector; Thakurdas et al., The "Bombay Plan." One expects the suspicion of private enterprise may have deep historical roots as the growth of the British Empire was tied to the success of the East India Company which had some very serious negative consequences for India. 
being run to maximize profits, but for a variety of additional reasons as well. $^{20}$ In light of this, it is unsurprising that such firms would not focus on efficiency as the aim of corporate governance.

This was accompanied by a series of enactments that worked as entry barriers to certain markets and to investment. First, there was a series of enactments that required industrial enterprises to obtain a number of licenses from various government agencies to conduct business or to expand capacity (commonly known as the "license raj"). ${ }^{21}$ The requirement to obtain the government's approval provided opportunities for rent-seeking and corruption that likely led to a less competitive environment for many Indian businesses. The lack of competition would have benefited incumbents, but would also have hindered further improvement in corporate governance by reducing the competitive pressure to be efficient.

Second, the government erected barriers to both foreign investment in India and to foreign competition. There were large trade barriers and tariffs accompanied by limits on how much stock a foreign entity could own in an Indian enterprise and requirements for firms to purchase their goods from primarily indigenous producers. ${ }^{22}$ This insulated domestic firms from foreign competition and, when combined with the extensive licensing requirements, insulated domestic firms from much further domestic competition.

This was compounded by how private sector firms were capitalized and the incentives of the various capital providers to monitor management. The primary source of capital for many Indian firms was debt capital. This was made available by the state through a variety of stateowned and -operated development finance institutions (DFIs). ${ }^{23}$ The performance of DFI employees was not assessed based on whether the firms they provided funding to made a profit, but rather on the total amount of loans that had been made. This, of course, created an incentive to maximize the amount of loans rather than providing loans to businesses with viable business plans. DFIs then had little incentive

20 Goswami, "India: The tide."

21 Goswami, "India: The tide."

22 Mohan and Aggrawal, "Commands and Controls"; Goswami, "India: The tide."

23 World Bank, India: Role of Institutional Investors in the Corporate Governance of their Portfolio Companies, World Bank Report (2005); Chakrabarti, Financial Sector; Omkar Goswami, Corporate Bankruptcy in India: A Comparative Perspective, Development Cent re Studies (Paris: Development Centre, Organisation for Economic Co-operation and Development; Washington DC: OECD Publications and Information Center, 1996). 
to monitor management. Indeed, the DFIs often favored management due to a variety of reasons including corruption and political gain.

Although the DFIs were often the primary credit providers, other creditors did exist and would have had some incentive to monitor management. This was, however, hampered by the glacial speed of India's bankruptcy process. There were inordinate delays in the process of restructuring and liquidating a firm (e.g., it could easily take 10 years to liquidate a firm) and this would have placed these non-DFI creditors in an unenviable situation. ${ }^{24}$ Indeed, it was not very common for private creditors to provide credit to anyone but blue chip companies or companies backed by government guarantees. Thus, these creditors were unlikely to exercise real oversight over management.

Even if creditors could not or did not monitor management, perhaps shareholders could. Here also there were problems. First, the primary providers of equity capital were the DFIs. Although most DFIs would provide finance primarily in the form of debt, they might also invest in the form of equity when their internal debt ratios would prohibit them from funding any more amounts as creditors. Indeed, for many companies the DFIs had collectively well over $50 \%$ of the equity stock. However, the DFIs had, as before, little incentive to act as careful monitors of management and used to routinely appoint nominee directors to the boards of these corporations that would rubber stamp the decisions of management ${ }^{25}$

If the DFIs did not exercise oversight, then what about other minority (non-management) shareholders - they might be able to exercise oversight. There was certainly provision in the Companies Laws for minority shareholders to raise oppression and mismanagement concerns at various adjudicative fora. ${ }^{26}$ However, they were unlikely to have their grievances redressed for the following reasons: ${ }^{27}$

First, the Indian judicial system was full of delays and years could pass before such litigation would be adjudicated. Second, there appeared to be many irregularities in the share transfer and registration process which would have further delayed minority shareholders in bringing their cases. Third, the disclosure of ownership structure and related

24 T. C. A. Anant and Omkar Goswami, "Getting everything wrong: India's policies regarding 'sick' firms," in Dilip Mookherjee (ed.), Indian Industry: Policies and Performance (Delhi: Oxford University Press, 1995); Goswami, Corporate Bankruptcy in India.

25 World Bank, India: Role of Institutional Investors; Goswami, "India: The tide."

26 See Sections 397 and 408, Indian Companies Act 1956.

27 Goswami, "India: The tide." 
party transactions was very opaque in India making it even harder for minority shareholders to achieve redress. This was exacerbated by the very high tax rates for corporations and individuals, which led to a tremendous amount of tax evasion achieved by devising highly complicated cross-holding structures. Although this aided tax evasion, it had the by-product of making ownership structure even more opaque to minority shareholders. Finally, even if someone tried to buy up shares in the corporation from the DFIs the government could block share transfers that might result in a change in the board that the government considered "prejudicial to the interest of the company or the public interest." Given that government (via the DFIs) tended to vote with management one can easily see how this would lead to entrenchment of management and little scope for effective oversight by other shareholders.

Of course, even if non-management shareholders and creditors exercise little oversight it may be that management has incentives aligned with maximizing wealth as most managements were the promoters and initial investors in the company. Here, too, capital structure played an invidious role. Because the ultimately passive DFIs provided so much of the capital (both debt and equity), the more active and interested promoters could maintain control with as little as 15 percent of the equity of a firm and, given the amount of funding they received in the form of debt, the promoters could have maintained control of a firm by providing only 3 percent of its capital. ${ }^{28}$ With such excessive leverage the promoters could recover their initial investment very early on. Moreover, with so little invested in the firm the promoters and management would face incentives that might diverge quite widely from the rest of the shareholders, including the inattentive DFIs. The prospect for selfdealing and moral hazard would loom large in this environment.

Of course, such a system should have led to considerable looting by management and many failed companies. Although the looting did occur, the system was insulated from some of the consequences of failed companies both by the slow bankruptcy process and by the fact that the state could take over failing businesses and keep them afloat to maintain employment. The employment dislocation that would otherwise follow such policies did not eventuate, but at the cost of increasing the effective debt burden for the state. ${ }^{29}$ 
Thus, by 1991 the Indian corporate scene had changed considerably from its pre-Independence situation, leading India to become a laggard in healthy corporate governance. For state owned enterprises the familiar story of lack of competition and little profit incentive contributed to the inefficiency of the enterprise and its atrophied corporate governance. For private firms corporate governance was ineffective for a number of reasons. First, the DFIs as large shareholders and creditors played little to no monitoring role given the structuring of their incentives and the political context in which they acted. Second, the non-DFI creditors could exercise only limited oversight given the very slow pace of bankruptcy proceedings in India. Third, minority shareholders (non-DFI shareholders) faced considerable obstacles in enforcing their rights. There were lengthy judicial delays, little information about related party transactions, opacity in ownership structure (largely motivated by tax evasion) and irregularities in transferring shares. Fourth, promoters could start firms by putting up only the smallest sliver of their own capital. When this was combined with the ineffective oversight by other parties the potential for mismanagement and fraud becomes quite large. Moreover, these private firms faced little competitive pressure to improve their efficiency because of the "license raj" system, which limited domestic competition, and the high trade and other barriers limiting foreign competition. Finally, the employment dislocation that might have been caused by very inefficient management leading to failed firms was not felt in its entirety because the state could take over failing firms and keep their work force employed. This would have reduced the political cost of supporting inefficient management.

This is a recipe for dysfunctional corporate governance and that is precisely what India had. In formal terms, India had the laws and the legal system to enforce good corporate governance practices, but the functioning of the system, the inconsistent disclosure requirements, and largely ineffective boards of directors created instead a failing governance system. Indeed, Indian firms that were looking for capital were forced to look primarily to internal sources or the capital provided by the DFIs. ${ }^{30}$

30 Asish K. Bhattacharyya and Sadhalaxmi Vivek Rao, "Economic impact of 'regulation on corporate governance': evidence from India," Indian Institute of Management Calcutta Working Paper No. 486/2004, January 17, 2004, available at Indian Institute of Management Calcutta Working Paper No. 486/2004, January 17, 2004 (2005), available at http:// 129.3.20.41/eps/fin/papers/0504/0504002.pdf; World Bank, India: Role of Institutional Investors. 


\section{Liberalization and corporate governance reform (From 1991 to the present)}

The sheer weight and cost of this system came crashing down on the Indian economy in 1991 when the Indian government, in response to a financial crisis, embarked upon a general program of liberalization. It was the advent of these 1991 reforms that would lead to the corporate governance reforms that are examined in this paper. Liberalization was to take the form of selling off some of the SOEs and beginning to sell off or rationalize the state's interests in other firms. Further, the DFIs were now to be assessed on "bottom line" measures (i.e., return on assets) rather than the amount of loans sanctioned or "assets" created. ${ }^{31}$ Moreover, trade barriers were to be reduced, foreign investment permitted (and even encouraged) and the "license raj" to be eased thereby permitting increased domestic and foreign competition. ${ }^{32}$ Thus, post-1991 India would have new competitive spaces opening up (where the SOEs would no longer be the sole provider of goods or services), old industries becoming more competitive with the inflow of foreign competition and new domestic competition, and government institutions more motivated by efficiency than before. Following this the government created the securities market regulator - the Securities \& Exchange Board of India (SEBI) - in 1992 and slowly granted it increasing powers and the mandate to regulate the many domestic stock markets in India. ${ }^{33}$ This was significant because SEBI could take on an adjudicatory role and thereby relieve some pressure on the court system and provide more timely resolution of disputes insofar as they had publicly traded equity. ${ }^{34}$

It is against this backdrop that corporate governance reform would develop in India. Indeed, one of the more unique things about Indian corporate governance reform is that it was initiated and initially pushed by industry. Although there were scandals in the Indian stock markets

31 Indeed, the DFIs were no longer provided the kind of subsidized access to funds they had in the past and they were sometimes merged with private entities (World Bank, India: Role of Institutional Investors in the Corporate Governance of their Portfolio Companies, World Bank Report (2005)). The primary DFIs before 1991 were: - IFCI, ICICI, IDBI, UTI, LIC, GIC and Public Sector Banks. Now there are 3 sets of Institutional Investors the DFIs, new private sector Mutual Funds, and Foreign Institutional Investors.

32 Anne Krueger (ed.), Economic Policy Reforms and the Indian Economy (University of Chicago Press, 2002); Goswami, "India: The tide."

33 The Securities and Exchange Board of India Act, 1992.

34 Delays in the Indian Judicial system are well known. See Bibek Debroy, "Some issues in law reform in India," in J .J. Dethier (ed.), Governance, Decentralization, and Reform in China, India, and Russia (Boston MA: Kluwer, 2000), pp. 339-68. 
following liberalization (and even before it), it was when industry got involved that reform moved forward quickly. ${ }^{35}$ The Confederation of Indian Industry (CII) drafted the first corporate governance code in India in 1998 and it was that code that formed the basis for Clause 49 of the Stock Exchange Listing Agreement. ${ }^{36}$ Indian industry pushed governance reform because access to capital was necessary to take advantage of the opportunities created by liberalization and to stay ahead of (or at least with) the competition. ${ }^{37}$ However, given the generally poor level of governance Indian corporations could not seriously expect domestic and foreign investors to provide capital without some greater assurance. ${ }^{38}$ Indeed, some outside enforcement (e.g., via SEBI or the exchanges) might be needed to bolster the credibility of any governance reform. Thus, the corporate governance reform movement in many respects was motivated by a desire to access capital markets to fund investment in new business opportunities or to enhance chances in current endeavors. Reform was also supported by the increasing presence of foreign investors, the Indian financial press being quite active, and the desire to access US and developed world capital markets. ${ }^{39}$

Following the 1998 CII code, SEBI decided to form the Kumarmangalam Birla Committee (KMBC) and commission a report on corporate governance reform leading to changes in the listing agreement of the stock exchanges. The KMBC's draft set of recommendations came out on 1 October 1999 and became effective as Clause 49 of the listing agreement with the exchanges on 21 February 2000 - a stunning 5 months later. Firms failing to meet the requirements of Clause 49 could be delisted. ${ }^{40}$ The details of Clause 49 are provided in Appendix 15.1, but a quick overview is provided below.

Clause 49 had both mandatory and non-mandatory requirements. In the mandatory portion were a number of reforms designed to require greater independence on boards. This involved prescribing minimum percentages of independent directors $(50 \%$ or $33 \%$ depending on whether the Chairman was an executive director) and significantly tightening up the definition of "independence." In addition, Clause 49 mandated

35 Goswami, "India: The tide."

36 See Confederation of Indian Industry, Desirable Corporate Governance: A Code (1998).

37 See Goswami, "India: The tide"; Chakrabarti, Financial Sector.

38 See Vikramaditya Khanna, "Corporate governance in India: Past, present and future?”(2009) 1 Jindal Global Law Review 171-95.

39 Goswami, "India: The tide."

40 Now there is the possibility of financial penalties from Section 23 E of 2004 Act. See Securities Laws (Amendment) Act, 2004, S.11. 
the number of meetings per year, expected boards to develop a code of conduct and imposed limits on the number of directorships a director could simultaneously hold. Clause 49 also enhanced the power of the audit committee both by requiring financial literacy, experience and independence, and by expanding the scope of activities on which the audit committee had oversight. Executives were also expected to be more personally involved in corporate affairs as seen by the requirements for certification by the Chief Executive Officer (CEO) and Chief Financial Officer (CFO) of financials and overall responsibility for internal controls. This was combined with considerably enhanced disclosure obligations (on many things including accounting treatment and related party transactions) and enhanced requirements for holding companies when overseeing their subsidiaries. These series of changes appear aimed at making boards and audit committees more independent, powerful and focused monitors of management. Moreover, the enhanced disclosure would aid institutional and foreign investors in exercising oversight as well.

A number of further committees were formed which made a series of recommendations (e.g., Naresh Chandra Committee, Department of Company Affairs Report, Malegam Committee, and the Narayana Murthy Committee) leading to further changes in the listing requirements. ${ }^{41}$ Additionally, amendments were made to the Companies Law and some proposals are still under consideration. Moreover, the corporate governance of banks was reformed at this time as well. ${ }^{42}$

Although there were some changes to the statutory law during this period, most of the changes were in the listing requirements. This is not too surprising. Changes in listing agreements carry the penalty of de-listing, which although significant, is less personally painful for executives than violations of the statutory law which could involve direct financial penalties and jail time. Moreover, listing requirements are generally enforceable only through SEBI and the exchanges which can utilize enforcement discretion thereby softening the impact of the changes. This would have dulled opposition to the reforms because the cost of non-compliance looks less severe. Indeed, a strategy of first changing listing requirements looks very much like an attempt to first

41 See Murthy Committee (2003); Chandra Committee (2002); Malegam Committee (1995).

42 Chakrabarti, Financial Sector. In banks the system of nominee directors is being phased out and the banks use the CAMELS system (Capital Adequacy, Asset Quality, Management, Earnings Liquidity and Systems and Controls). See Murthy Committee (2003); Chandra Committee (2002); Malegam Committee (1995). 
"test the waters" in a relatively low cost way, so that if the change "sticks" regulators can proceed with statutory changes thereby providing firms with sufficient time to adapt before penalties became more significant. Such a strategy is less likely to encounter political opposition and may still provide enough assurances to encourage the investment of capital in India. This is certainly a plausible way to describe the reforms that have occurred in India.

Indeed, consistent with this the next series of important reforms are statutory changes which are to be tabled in front of Parliament soon (based on the J. J. Irani Committee's (2005) recommendations). ${ }^{43}$ The changes will apply to all firms in India (not just those listed on the exchanges). The proposed changes are summarized in Appendix 15.1 and compared to the changes wrought by Clause 49 .

From our perspective a number of things are noteworthy about the Irani Committee's recommendations. Although they tighten up certain things and loosen others relative to Clause 49 , the overall thrust of the recommendations is that the statutory law will permit greater customization and self-regulation (e.g., requiring shareholder approvals for executive compensation) for all companies. Moreover, this will be accompanied by greater protection for smaller shareholders, especially in merger transactions. Finally, the process of enforcement is to be streamlined, the bankruptcy system upgraded, and the actual legal provisions rationalized and simplified (eliminating redundancies and so forth). These changes are not inconsistent per se with Clause 49. This is because Clause 49 is specifically targeted at listed companies and one might expect tighter regulation for these kinds of companies (as they raise capital from the general public) compared to all firms (listed or not) which may raise capital from smaller and perhaps better informed sets of people.

One could, of course, view the Irani Committee as taking a more cautious approach to governance reform than Clause 49. This is perhaps not that surprising given that India attracts much more capital now than it did before the enactment of Clause 49 (indicating that the marginal gain from governance reform now may not be as large). In addition, there are many firms who have had difficulty in complying in a timely manner with Clause 49, indicating that further reform may be fairly costly on top of the reforms in Clause 49.

43 See "Cabinet approves Companies Bill," The Times of India, August 30, 2008. There is also some further movement on disclosures as per the Parekh Sub-Committee Report (2008). 
Although these governance reforms are important, there are many others one could also examine and reform: voting rights, bankruptcy reform, and perhaps shareholders suits. Indeed, one might view the above-described changes and proposed changes as just parts of a broader package of reforms that make capital investment or lending more attractive in India.

\section{The development of corporate governance in China}

Any discussion about corporate governance - and more recently improved corporate governance - in China must be prefaced by background on the broader reform of China's post-1949 centrally planned, state-owned, economic system and the subsequent formal corporatization of state-owned asset groupings. In a word - before there could be "corporate" governance or corporate governance "reform," there had to be corporations. In the initial stages of Chinese reform, corporatization was the repositioning of line-Ministry operated factories and other stateowned assets under the umbrella of independent legal persons established under law. ${ }^{44}$ Only in the last decade and a half - and after the growth of domestic capital markets, the creation of a distinct private and public shareholder class (Chinese and foreign), and the appearance of more independent (and themselves corporatized and profit-seeking) providers of credit - have these re-organized asset groupings and their new corporate identities become the focus of what Chinese participants and academic observers theorize as corporate governance "reform." Thus, we begin our analysis of corporate governance reform in China by addressing (i) how the industrial enterprise system was organized in the PRC prior to reform, (ii) the actual process of corporatization (not "privatization") which commenced in the mid-1980s and continues today, and (iii) the shifting policy goals over two and a half decades which have animated adoption of the corporate form generally in reform-era China.

If, as we posit above, the story of modern corporate governance in India calls to mind the tale of the "prodigal son," then China's encounter with the corporate form is something more alarming to the receiving

44 As will be alluded to below, this process should not be called "privatization" as such newly established legal entities continued to be largely owned, and controlled, by state administrative departments, themselves reorganized as "holding companies" or "controlling groups." 
parents - the arrival on the family doorstep of a fully formed, overseasadopted (or at least foreign-educated) child one had no expectation of ever meeting, much less letting onto the premises to race around the house freely!

\section{A. From the Communist Revolution to the start of the reform era (1949 to the mid-1980s) - Policy reforms}

The post-1949 Chinese economic system was characterized by an overwhelming reliance on two key mechanisms: (i) central planning and (ii) direct bureaucratic-administrative control of the industrial economy's productive instruments. ${ }^{45}$ Productive assets in China were organized as SOEs (usually as part of coterminous "work units") under "line Ministries" reporting to the State Council. These Ministries and their subordinate bureaus acted as agents of the state in operating the SOEs under their charge, with the state in turn deemed to be the representative of the ultimate owners - "all the people." 46 This structure was consistent with orthodox Marxist ideology, and the requirement that ownership of the means of industrial production be vested in a certain very large group of politically privileged citizens. ${ }^{47}$ That ideological characterization dovetailed nicely with the Chinese leadership's perceived requirements - especially after the destruction and dislocation of the

45 The summary provided here is an over-generalization. In truth, the organization of the Chinese industrial economy even pre-reform was far more complex and highly differentiated. See Barry Naughton, Growing Out of the Plan: Chinese Economic Reform, 19781993 (Cambridge University Press, 1995). However, our summary description in this article should prove useful as a template to understand the (under-performing if not failing) system in place prior to generalized reform and then implementation of the specific remedy directed at failing SOEs, corporatization.

46 The term "state-owned enterprises" in English is in fact a translation of the Chinese term more literally rendered "owned by all the people-system enterprises" (quanminsuoyouzhi qiye). Chinese Communist Party (CCP) organizational structure closely shadowed the governance structure of SOEs and in fact possessed far more power than formally designated enterprise "managers." Even after corporatization and global public offerings by transformed SOEs, Communist Party cells or committees continue to have huge governance power over Chinese firms, usually more power than the formal board of directors, independent directors, or senior management. With respect to the corporatized commercial banks alone, see Nicholas Calcina Howson, "China's restructured commercial banks: The old nomenklatura system serving new corporate governance structures?" in M. Avery, M. Zhu and J. Cai (eds.), China's Emerging Financial Markets: Challenges and Global Impact (Singapore: John Wiley and Sons, 2009).

47 Under the Chinese revolutionary scheme, a wider group than merely the "proletariat," and thus inclusive of workers, peasants, military - but excluding those declared to be without political rights (class enemies, criminals, etc.) 
Anti-Japanese War, World War II, the Chinese Civil War and eventual Liberation (in 1949) - for strict central control and planning of the industrial economy. At the lowest reaches of this system was the "work unit" or danwei, often coterminous with specifically identified SOEs but also sometimes subordinate units aggregated into a larger SOE. These work units operated at the instruction of the planning bureaucracy and had little autonomy. In theory, work units/SOEs were allocated inputs or other necessary resources by government bureaucratic actors and then closely instructed on production requirements (usually set as quotas or directed production levels). The SOEs then distributed product through mandated channels to specified buyers, and collected revenues determined according to state-controlled pricing. Gross cash in-flows to SOEs were immediately remitted, in toto, to the SOE's planning or administrative superior (i.e., a bureaucratic actor in the line Ministry system), with that superior body subsequently re-allocating cash back down to the SOE/unit to fund the next temporal cycle of productive activity. Importantly, these SOEs/work units also bore the very significant burden of certain "social" or non-economic tasks - delivering housing, medical care, education, day care, retirement support and even entertainment for members of the unit or SOE (including their non-employee family members).

At least until the early 1980s then, SOEs and the SOE system were strangers to common aspects of corporate structuring or corporate law. For example, SOEs did not have distinct legal personality, did not contract as independent legal persons, and did not formally "own" assets they operated or controlled. Instead, SOEs were essentially arms of the state bureaucracy and as such were not separate from the political or administrative authorities. They merely "operated" but did not "own" the assets assigned to their charge. The SOE structure, when set against the background of the Communist Party-ruled state, resulted in SOEs managed almost entirely by planning and political authorities. This in turn had important effects on how these entities were governed:

First, there were no identified owners of the SOEs (only the political fiction of "all the people"), and thus no specific or human actor interested in the performance or growth of the assets collected under the umbrella of a given SOE. Monitoring by "all the people" was impossible, even if sincerely intended, because of the most severe kind of collective action problem. The only authority which could monitor the SOEs and their managers were the state-bureaucratic organs to which management of these enterprises was formally delegated. In any case, at this time SOEs were not 
tasked with pursuing profitable activity - instead, they were responsible for fulfilling the commands of centralized planning authorities, using centrally allocated funds to manufacture goods, and sell products to stipulated buyers at state-controlled prices. Thus, "monitoring" of SOEs consisted of passive acceptance by higher administrative authorities of annual confirmations by subordinate SOE groupings with respect to whether these instruments of the planned economy (and indirectly their managers) had fulfilled quota production or distribution targets. Likewise, because the aim of such SOEs was not to create profits or grow value but to fulfill commands. There was no requirement for profit accounting, merely cost accounting to track mandated inputs and directed outputs. Similarily, because growth of the enterprise qua SOE was entirely irrelevant, there was no need for a balance sheet to understand the changing value of the SOE firm. Thus, even if there was a party interested in monitoring the firm, the measurement of performance and value on an enterprise basis would have been near impossible.

Second, the sole provider of credit to significant SOEs was the stateowned and controlled banking system (excepting direct cash allocations by government and planning authorities). In effect, banks were merely an alternative mechanism for planned allocations of capital by the state directly to SOEs. The banking system itself, and the instruments of that system, were equally unconcerned with profitability, efficiency or return on assets. As a result, there was no inquiry by these credit providers as to the creditworthiness or profitability of the "borrower" SOEs, and scant concern or expectation that such borrowers would pay interest or even principal. In this context, the state banking system had little incentive to monitor SOEs (or their managers') performance. These difficulties were only intensified by the lack of any hard budget constraint at the SOE enterprise level, even a notional bankruptcy threat, or a legal structure for security interests and exercise of the same by the providers of credit. In short, under the pre-reform structure, even the providers of credit to productive SOEs had no monitoring interest or incentive whatsoever.

Thus, the historical SOE system was characterized by an absence of any monitors of enterprise profitability, much less methods to assess the performance of those individuals entrusted with operating the SOEs. Instead, performance evaluation focused on conformity with top-down bureaucratic commands, with little or no connection to the most efficient or productive utilization of state assets. Indeed, performance evaluations for SOEs may well be termed almost entirely political (or bureaucratic) and opaque to any external actors. 
After the end of the Great Proletarian Cultural Revolution and the death of Mao Zedong in 1976 it was widely recognized that the SOE system, in large part because there was no effective monitoring, furthered widespread inefficiency, low factor productivity, and wastage in key capital intensive industrial sectors. ${ }^{48}$ Accordingly, and starting in the late 1970s, China began far-reaching policy reforms of the SOE system to attack widely acknowledged SOE inefficiency. ${ }^{49}$ In particular, the PRC allowed substantial liberalization of so-called "collective enterprises" (not SOEs) and permitted the establishment of foreign-invested enterprises primarily project-specific joint ventures between inefficient S.OEs and foreign investors matching cheap labor with foreign capital and technology to produce exported consumer goods. ${ }^{50}$ Moreover, for SOEs, new measures were implemented that provided key managers with personal incentives to be concerned with SOE asset productivity, and provided

48 Nicholas R. Lardy, China's Unfinished Economic Revolution (Washington DC: Brookings Institution Press, 1998).

${ }^{49}$ See Stoyan Tenev and Chunlin Zhang, with Loup Brefort, Corporate Governance and Enterprise Reform in China: Building the Institutions of Modern Markets (Washington DC: World Bank; International Finance Corporation, 2002), pp. 10-16; Naughton, Growing Out of the Plan, pp. 57-170; Lardy, China's Unfinished Economic Revolution, pp. 21-58. Some of these policy reforms were subsequently codified in what was presented as "law," as the PRC's parallel "legal construction" program gathered steam and substance.

50 There were smaller scale enterprises (collectively owned enterprises and some truly "privately"-owned enterprises) in some areas. "Collectively owned" refers to the idea that these were "owned" by a local level collective - of ten a local-level government body and employee workers - and not fully nationalized or state-owned, at least not by central state authorities. However, this formal "ownership" by the collective did not imply any kind of governance power over the collectively held assets, or profit participation in the collective's revenues, made clear only in subsequent laws applicable to such collectively owned entities. In fact, many of the successful collectives were corporatized after the 1994 Company Law was passed, as much to get governance and profit-sharing benefits as to prepare for public listings. Chinese-foreign joint ventures allowed SOEs to contribute state-owned assets already entrusted to the SOEs into new, independent, "legal persons" (these foreign-invested enterprises became China's first post-1949 corporate entities). It has become clear that these Chinese-foreign joint ventures contributed mightily to fueling China's exploding export sector. But at least one study suggests that the initial program of attracting direct foreign investment had detrimental effects because it kept bankrupt SOEs afloat and diverted foreign capital investment away from more efficient and entrepreneurial, but less politically favored, enterprises. See Yasheng Huang, Selling China: Foreign Direct Investment During the Reform Era (Cambridge University Press, 2003). Finally, SOEs could also at this time re-position state-owned assets under "joint enterprises" (lianying qiye), which were permitted to operate more autonomously than SOEs. These gained a formal basis in law only with the General Principles of the Civil Law 1986. See Zhonghua Renmin Gongheguo Minfa Tongze (The General Principles of the Civil Law of the People's Republic of China), Articles 51-3. 
institutional incentives to force the SOEs themselves to operate more efficiently by tying the amount of resources the SOEs could retain at the enterprise level (or not submit to the government directly) to their economic performance. ${ }^{51}$ Thus, the "better" the SOE performed, the more cash assets (as retainable revenues) it could maintain under its control - something of considerable benefit to the SOE and SOE management. Although not quite the same as a profit mechanism, this key reform was designed to provide enterprise management with incentives to boost performance at the SOE level.

At the same time, there were very early stage changes to the banking system, ${ }^{52}$ whereby banks were made notionally more credit-oriented in continuing to dole out planned capital allocations in the form of "bank loans." Moreover, 1986 saw the promulgation of an "experimental" Bankruptcy Law applicable only to SOEs. This was an important (future) marker for the legal consequences and creditor's rights arising after the imposition of a real hard budget constraint on enterprises. Although important from the perspective of putting these issues on the table, these developments had little real bite as there was - in these early days - no true hard budget constraint at the enterprise level, a notional bankruptcy constraint which was rarely applied, and bank loans distributed according to political signals rather than credit signals, even by purportedly "commercial" lenders.

By the end of this initial - primarily policy-based - period of reform, enterprise governance had improved somewhat as SOE management had slightly better internal incentives to operate more efficiently. However, the system still left very much to be desired in terms of external monitoring of PRC firms - the kind of external firm monitoring needed to significantly enhance efficiency. ${ }^{53}$

51 This included the use of dual track pricing (designed to introduce market incentives and re-orient SOE production) and liberalization of the labor markets thereby allowing for the possibility of dismissing certain workers.

52 The People's Bank of China, China's sole domestic lender, spawned three new banks People's Construction Bank, Industrial and Commercial Bank, and Agricultural Bank of China - to exist alongside China's pre-Liberation foreign exchange banking institution, the Bank of China. For a more detailed treatment of the full banking reform agenda, from the mid-1980s to 2009, see Howson, "China's restructured commercial banks."

53 Chinese policy makers apparently sincerely believed that net changes in the way SOEs were managed - when matched with increased marketization of the external economy within which such firms acted - would lead to corresponding productivity and efficiency gains from the SOEs themselves. Notwithstanding a great deal of rhetoric, policy pronouncements, and promulgation (if not implementation) of "laws" and "regulations" and other "normative documents," many of the external and internal incentives (or disincentives) shaping enterprise performance remained very weak. 
It is also important to note that these changes were not implemented (i) through formal corporatization of the firms or (ii) under law. This policy-inspired reform approach can be seen clearly in the PRC Law on Enterprises Owned by All of The People (SOE Law) ${ }^{54}$ That "law" is in fact a catalogue of reform policy choices and aspirations rather than an enforceable statute. ${ }^{55}$

\section{B. Formal reorganization of the industrial economy} and corporatization (from early/middle 1980s to date)

Formal corporatization of Chinese assets really began in the early 1980s, as part of self-declared "experimental" programs undertaken at local (sub-national) level government initiative. ${ }^{56}$ In large part, these efforts were directed at the corporatization of (or in the accepted Chinese idiom, use of the "share system" (gufenzhi) by) smaller, and locally promoted, collectively owned enterprises. As an example, local governments made a practice of foregoing collection of an array of fees or taxes from pre-existing collectives, either for a recognized profit participation

${ }^{54}$ Quanminsuoyouzhi Gongyeqiye Fa (Law on Industrial Enterprises Owned by All of the People), adopted at the First Session of the Seventh National People's Congress and promulgated by Order No. 3 of the President of the PRC on April 13, 1988, and effective on August 1, 1988.

55 Thus, while the SOE Law does provide one of the initial confirmations, in law, of legal personality, hard(er) budget constraints, and independent accounting for SOEs, the SOE Law is really only a strong policy statement dressed up as a "law" designed to express the increased responsibilities and powers of factory/SOE managers, and the uneasy balance between state planned activity and the productive ambitions of SOEs themselves. Article 2 of the SOE Law says it quite well:

[the SOE is] a socialist commodity production and operation unit that shall, in accordance with law, make its own management decisions, take full responsibility for its profits and losses, and practice independent accounting. The property of the enterprise shall be operated and managed by the enterprise with the authorization of the state in line with the principle of separation of ownership and management authority. The enterprise shall enjoy the right to possess, utilize and dispose of, according to the law, the property that the state has authorized it to operate and manage.

Perhaps the most interesting question about the promulgation of the SOE Law pertains to why the Chinese government saw the need to promulgate it. Was it merely something deemed consistent with the appearance of the legal construction program then moving into high gear, or was it a political/institutional marker to establish basic, and presumably irreversible, policy choices for all actors in Chinese society?

56 These initiatives were undertaken first without any basis in national law or local-level or administrative regulation. 
in the collective's future earnings, or something like "founders equity" in a formally re-organized, or even subsequently corporatized, collective. ${ }^{57}$ In those very early days, one of the primary perceived benefits of corporatization - at this very local level - was the relatively painless and cost-free creation of non-transferable "equity" interests in Chinadomiciled firms, which were used (oppressively in some cases) in lieu of unavailable cash compensation for employees.

The great impetus for wide-scale corporatization of China's SOEs and eventually transformed collectively owned enterprises was capitalraising. As early as 1984, eleven SOEs became "shareholding system enterprises," with a number of other corporatizations of SOEs completed before the end of that decade. ${ }^{58}$ The almost premature establishment of Chinese stock exchanges at Shanghai and Shenzhen in 1990-1, and the speculative frenzies resulting immediately, only heightened the attractive pull of the corporatization idea. ${ }^{59}$ Above all, corporatization reform at this stage was animated by what must have appeared to be an easy bargain for Chinese enterprises and their bureaucratic (central or local) masters: the ability to attract financing (Chinese and, almost immediately, foreign) ${ }^{60}$ for poorly performing SOEs, but without any dilution of the state's near absolute control in the resulting corporate entities. ${ }^{61}$ That being said, it is also clear that many reformist policy makers in China understood corporatization and the listing of shares on public exchanges - domestic or foreign - as a useful first step to increased monitoring of Chinese enterprises by public markets (both via market valuation and participation by shareholders in governance), even if that would come at some time in the very distant future.

In November 1993, the Chinese Communist Party officially unveiled and provided political sanction for the "modern enterprise

57 See, eg., background to the formation of Stone, China Legend (now "Lenovo"), Hai'er, etc.

58 See Tenev and Zhang with Brefort, Corporate Governance and Enterprise Reform, p. 16.

59 The frenzies, and in one August 1992 case surrounding the distribution of subscription forms for the Shenzhen Development Bank where riots resulted, led directly to the creation of China's powerful securities regulator, the China Securities Regulatory Commission (CSRC).

60 We note that the first public offerings on the Shanghai and Shenzhen Stock Exchanges were for the equity in transformed Chinese-foreign equity joint ventures ("transformed into what?" lawyers might ask in the absence of a company statute) and directed to foreign purchasers of "B" shares.

61 The fact that many participants saw the bargain as "easy" in the late 1980s and early 1990s does not refute the reality of the Faustian bargain struck in fact, as real governance constraints began to bite ten to fifteen years later. 
system." 62 This signaled the introduction and acceptance into China of the corporate mechanism and its attendant structural (legal), governance and management norms. Perhaps most important in the PRC context was the acceptance by the ruling Party of separation of the state's continued ownership rights (in the corporate legal person) on one hand, and the corporate legal person's exercise of ownership rights over the assets it now "owned," on the other. This political (note, not yet legal) pronouncement was the culminating policy-ideological expression of the long effort to maintain state "ownership" of the means of production, while at the same time creating real incentives for management autonomy (and property rights) at the enterprise level. ${ }^{63}$

Although a considerable move forward, the declaration of the age of "modern enterprise" in China did not enhance the governance situation at firms appreciably. The state remained the largest shareholder (in the 70-80\% range) and was still essentially "absent" as a shareholder interested in enterprise profitability. That "absent" but formal shareholder was also still far distant from insider (cadre) managers who more often than not fell prey to the temptations of opportunistic behavior with regard to the corporate assets left in their charge. Credit providers remained state-owned and run by Communist Party cadres, and were of ten captured by local-level government-dominated branches with interests closely aligned to the same local level government insider managers. Finally, even as China's "legal construction" program continued apace, there was little corporate or securities law designed to protect the interests and monitoring rights of those who provided real capital, and the weak courts did not have the competence, political strength or will to enforce what law and regulation there was.

\section{Company law and China (1993-2006)}

In 1993, in line with the simultaneous policy confirmation of the "modern enterprise system," China's legislature promulgated China's first, and deeply flawed, post-Revolution Company Law - which law

62 See Third Plenum of the Fourteenth Congress of the Chinese Communist Party, "Decision on Issues Concerning The Establishment of a Socialist Market Economic Structure."

63 This same Decision from the Third Plenum of the Fourteenth Party Congress also ratified, and made ideologically "safe," a development already far advanced - the rise of so-called "diversified forms of enterprise ownership": individually owned, privately owned and foreign-owned enterprises. 
became effective on July 1, $1994 .^{64}$ That law (along with China's Securities Law 1999) was subject to wholesale and rather significant amendments in late 2005, which came into effect on January 1, 2006. Yet, even with the 2005 amendment of these basic statutes, the corpus of corporate or company law in China today is by no means limited to a single statute which is called the "Company Law" or, with respect to listed companies, the "Securities Law." A great deal of China's corporate law-making and regulation, and many would argue corporate law that is more readily enforced, is found elsewhere. The great source of this regulation in modern China is the China Securities Regulatory Commission (CSRC), the administrative agency specifically charged with governing public (listed) company activity and all securities trading.

Since 1994, China's central government, the legislature, and the CSRC have accepted - with some pronounced and rather awkward exceptions the rhetoric of the "standard shareholder-oriented" model of corporate law and governance. ${ }^{65}$ At the same time, it was quite clear that until 2005

${ }^{64}$ The history of corporate law in China actually stretches a full ninety years before the enactment of the 1994 Company Law: on January 21, 1904, the then newly created Ministry of Commerce under the declining Manchu Qing Dynasty promulgated a Company Law (Gongsilu). See Wellington K. K. Chan, Merchants, Mandarins and Modern Enterprise in Late Ch'ing China (Cambridge MA: East Asian Research Center; Harvard University Press, 1977). Chinese scholars trace the first corporate (albeit experimental) establishment to 1873, with the promotion of the Lunchuan Zhaoshangju (China Steam Merchants Company) and some go even farther back in time to the 1.700s and invoke the formation of Sichuan's "contracting stock system" (qiyue gufenzhi) enterprises and their essential corporate characteristics. See Jiusong Peng, Zhongguo Qiyue Gufenshi (China's Contracting Stock System) (1994). China's efforts at company law between 1904 and 1948 were directed towards several clear aims: creating a tool for China's industrial development (especially in competition with foreign companies making their presence increasingly felt on Chinese soil); attaining perceived "Western" or "modern" standards of law (with the hope that this would lead to the abolition of "extraterritoriality" imposed upon China after the Opium Wars); and, perhaps most importantly, but never explicitly, strengthening central government power. See William C. Kirby, "China unincorporated: Company law and business enterprise in twentieth century China" (1995) 54(1) Journal of Asian Studies 43. Many of the same things motivate the creation and implementation of a corporate law for China in the present age. On the US and UK influence, and the use of "modern" corporate law as the price of winning freedom from the burden of "extraterritoriality," see Lanxin Xiang, Recasting the Imperial Far East: Britain and America in China, 1945-1950 (Armonk, NY: M. E. Sharpe, 1995).

65 This suggests a high degree of formal convergence. See Henry Hansmann and Reinier H. Kraakman, "The end of history for corporate law" (2001) 89 Georgetown Law Journal 439. At the same time, PRC corporate law evidences some continuing loyalty to other models, including the "manager-oriented" and "state-oriented" models (conflated into one) or the "labor-oriented" model. For instance, a separate and inconsistent chapter was inserted into the Company Law to address a sub-species of the limited liability company form: the so-called "wholly state-owned company" (guoyou duzi gongsi): state 
various institutions in China were not deemed sufficiently ready to bear the full burden of corporate law duties and adjudication. ${ }^{66}$ Indeed, as Black and Kraakman note about emerging markets generally, and which is wholly applicable to China even thirty years after the start of "legal construction": "[a] company law that depends on fast and reliable judicial decisions is simply out of the question." ${ }^{27}$ So it was that the Chinese corporate and securities law system - at least in form - initially had many features of the "self-enforcing" model, including enforcement of norms by voting rules and transactional rights granted to direct participants, reliance on procedural protections and even pr,hibitions of disfavored transactions, attempts to invoke bright-line rules, a rhetoric (if not always the reality) that privileges the protection of "minority shareholders," and some expression of legal remedies (administrative and criminal) in formal law and regulation. Notwithstanding the understandable initial orientation toward a "self-enforcing" system, Chinese law academics, drafters and officials have focused more recent efforts in the service of corporate governance mechanisms requiring ex post judicial interpretation (e.g., fiduciary duties, piercing the corporate veil, derivative actions, etc.), as expressed in the 2005 Company Law effective January 1, 2006, ${ }^{68}$ while maintaining a good number of

administrative department-invested and -established legal person entities, which have n• shareholders' meeting, but which do have boards of directors which delegate management to an executive group. There seems little doubt that this section was inserted into the Company Law as a sop to certain political and economic actors in China who saw corporatization as the prelude to real privatization. Fealty to the European style of "labor-oriented" corporate entities is revealed in China's corporate structures wherein a "supervisory board" is required of such companies. The truth in today's China is, however, that such supervisory boards are established in formal terms, but ignored or misunderstood over the life of the company.

${ }^{66}$ See Chunying Xin, 'What kind of judicial power does China need?' (2003) 1(1) International Journal of Consititutional Law 58; Randall Peerenboom, China's Long March Toward Rule of Law (Cambridge University Press, 2002), Chapter VII; Donald C. Clarke, "Power and politics in the Chinese court system: The enforcement of civil judgments" (1996) 10 Columbia Journal of Asian Law 1.

67 See Bernard S. Black and Reinier H. Kraakman, "A self-enforcing model of corporate law" (1996) 109 Harvard Law Review 1911. Black and Kraakman include the 1994 PRC Company Law in their chart Survey of Company Law in Emerging Markets at the end of the article, with China deservedly scoring well from a purely formal standpoint.

68 For one recent study which indicates pre-2005 convergence over ex post corporate governance mechanisms by China's much-maligned courts - at least with respect to traditional Anglo-American fiduciary duties. See Nicholas Calcina Howson "The doctrine that dared not speak its name: Anglo-American fiduciary duties in China's 2005 company law and case law intimations of prior convergence," in H. Kanda, K. Kim and C. Milhaupt (eds.), Transforming Corporate Governance in East Asia (Abingdon: Routledge, 2008). 
self-enforcing mechanisms (mostly super-majority and recused shareholder votes).

\section{Focus on corporate governance reform in China (late 1990s to 2006)}

Even with the arrival of a new machine - the corporate entity - and attendant legal and regulatory norms, the varied and ingenious abuses or simple dysfunctions quickly seen at China's new corporations, especially those publicly listing a portion of their capital, almost beggar comprehensive description. As Stephen Green wrote in 2003 with respect to PRC companies listed on China's domestic stock exchanges:

China's stock market, ... was not a vehicle for privatization: whenever companies were listed the state retained large controlling stakes. As a result, the market has evolved into a dysfunctional halfway house, where neither public officials nor private shareholders enjoy effective control over most listed firms, and few in management have incentives to help their firms create value ... The poor quality of listed companies is the cause of the market's most serious problems, and until corporate performance and governance standards improve, there will be no significant improvement in the market as a whole. ${ }^{69}$

Green echoes an observation that we make above: a significant problem for China's new companies is not that there is an oppressive principal shareholder (the state or local governments), but that there is no principal, or an "absent principal." The formal owner of the corporatized firm (just like the "all the people" deemed owners of the predecessor SOEs) is too amorphous and attenuated to do anything but cede control to opportunistic, or just incompetent, insider managers. ${ }^{70}$ It takes no great imagination to understand some of the ways in which Chinese companies have been misgoverned and abused by other actors in the new corporate scheme. ${ }^{71}$ Indeed, with the rise of the "modern enterprise system", public listings of firms, and widely reported abuses, a virtual

69 Stephen Paul Green, China's Stock Market: A Guide to its Progress, Players and Prospects (London: Profile, 2003), p. 118.

70 See also Donald C. Clarke, "Corporate governance in China: An overview" (2003) 14 China Economic Review 494.

71 Examples abound and include: blatant self-dealing and overcompensation of insider managers; political interference in operations; disregard of minority shareholder interests and accounting problems. Moreover, due to the absent principal problem, sometimes even the controlling shareholder (the state or local government-backed shareholder) will cede effective control to either (i) large holders of "legal person shares" (farengu) (often local government or local level identities of present or former line 
obsession about "corporate governance" (gongsi zhili) has arisen inside China - among both the professionals, investors and analysts who seek to understand China's progress, ${ }^{72}$ and the retail "punters" who seem willing to participate in what prominent reformer $\mathrm{Wu}$ Jinglian has called "a casino." Although this obsession has focused, mistakenly we assert, on aspirations for traditional Berle and Means separation of ownership and management (and the remedying of related agency problems), ${ }^{73}$ the general movement has also been concerned with the growth, and overall health, of liquid and deep stock markets.

Whether or not China's domestic stock markets are what Professor Wu decries as a "casino," real and perceived weaknesses in the governance of China's listed companies have had a decidedly negative impact on the overall value of China's capital markets. Indeed, the result to 2005 and then after Spring Festival 2008 appeared to be a nightmare vision that Bernie Black borrows from the insurance sector - a "death spiral," where information asymmetry and adverse selection "combine to drive almost all honest issuers out of the market, and ... drive share prices to zero." ${ }^{74}$ While Chinese stock prices have not been driven to "zero," and politically privileged issuers continue to seek listings or follow-on

Ministries), or (ii) politically qualified (or local-government backed) managers or insiders.

72 It is important to note that this focus and enthusiasm pre-dated corporate governance scandals and headlines in North America and Europe, and was inspired by an active, reformist and very learned cadre of of ficials working at the CSRC in the periods 1992-5 and then 1999-2003. The power and influence of these individuals, many trained in the United States and Commonwealth countries with experience at international law firms, global accountancies and banks, was very seriously compromised by revelations about Enron, WorldCom, Arthur Andersen, etc because these individuals had vouched for a securities regulation and corporate governance system based on US models. These failures, which occurred under the watch of the then-recommended public disclosure (and independent accountancy) system, were used by opposing political forces to remove those same of ficials from the commanding heights of China's corporate and securities regulatory structures.

73 The focus has been almost entirely on (i) Chinese SOEs, most often once formal separation of ownership and management is effected and they are transformed into companies limited by shares under the PRC Company Law, and (ii) listed companies (regardless of where they list their stock), which are necessarily companies limited by shares. See Clarke, 'Corporate governance in China'. This focus is unfortunate because there are many governance issues for other legal and spontaneous forms as well as private (non-listed entities). See for instance, Dehua Tang (ed.), Qita Gongsi Zuzhi Xingshi Yu Gufen Hezuo Qiye Falu Shiwu (Legal Treatise on Other Firms of Corporate Organization and the Stock Cooperative Enterprise) (1998), p. 219.

74 Bernard S. Black, "The core institutions that support strong securities markets" (2000) 55 Business Lawyer 7. 
offerings, the trend over the past ten years (with the intermediate surge resulting from initial announcement of the "stock rights reallocation initiative" (guquan fenzhi) and rather blind foreign interest in public Chinese equities suddenly accessiable via a Qualified Foreign Institutional Investor (QFII) program) has been volatile. This situation had made the Chinese domestic exchanges a potentially unattractive place to raise money, both for the large reformed SOEs, which are permitted to issue and list shares on such exchanges, and the smaller, sometimes truly private, entities which have not generally been allowed wide access to the same markets. ${ }^{75}$

In recent years, along with revision of China's corporate and securities law statutes in $2006,{ }^{76}$ the PRC has taken important steps to reform (rather than merely establish) corporate governance. For instance, the 2006 Company Law finally establishes that companies limited by shares (gufenyouxianzeren gongsi) ${ }^{77}$ possess the five basic features of AngloAmerican corporations, which are: (i) full legal personality for the firm, (ii) limited liability for shareholders; (iii) shared ownership in the firm by investors; (iv) formal separation between ownership and management, with management being delegated by the owners (shareholders) to a board of directors, and then to a management group; and (v) transferable share interests (transferability is a very complex question in the Chinese context; a multitude of restrictions work on the proposed transfer of share capital in China, listed or not, in most cases depending upon who or what owns and is seeking to transfer shares). Numerous other legal and regulatory changes have been implemented in the same period, many of which are invoked below. Overall, the changes effected in the last half decade or so have led to (i) changes in the expectations (and hence demands) of investors, (ii) an increase in the efforts of the CSRC, and indirectly the courts and the media, to enhance governance,

75 As a result, they are forced to rely upon foreign investment, bank intermediaries (which are undergoing their own liberalization), intra-group financing, or the insufficient drip of retained earnings.

76 Some of the changes - not dealt with in depth here - impact upon the symbolic or rhetorical nature of the Law. For instance, literally hundreds of allusions to the "state's" role in corporate formation, governance and business decision making has been washed out of the new law's text.

77 The PRC Company Law allows for two basic corporate forms, both of which confer limited liability for shareholders: companies limited by shares ( gufenyouxianzeren gongsi) and limited liability companies (youxian zeren gongsi). The former is similar to what in American parlance is called a joint stock company; the latter is more like a closed corporation or corporate partnership. 
(iii) greater, or more clearly specified, legal obligations on management and controlling shareholders, (iv) better access to court enforcement of governance via permitted shareholder suit mechanisms, and (v) the potential for increased monitoring by credit-evaluating financial institution lenders. These changes suggest that we might begin to see greater monitoring by the primary credit and equity providers in China (due to their increasing presence and greater incentives than before) which, when supplemented by law that is technically better and potentially greater enforcement, provides a more promising future for governance. We summarize only the most important steps below.

\section{Investor expectations}

Investor expectations in China have begun to change for a number of reasons. First, China continued to corporatize SOEs and collective enterprises or township and village enterprises (TVEs). The increasing issuance of equity interests to the public and other independent and commercially concerned (if often local government-backed) entities has introduced new owner-shareholders who have had a very significant impact on the way such enterprises are operated, and in whose interest.

Second, and relatedly, corporatization of wholly domestic firms was preceded by the introduction of foreign equity investors in or alongside PRC enterprises. Indeed, this program commenced with private FDI from the first moments of China's Reform and Opening to the Outside World policy. ${ }^{78}$ Since the early 1990s, the PRC has pursued a very successful program to attract foreign investment to finance Chinese corporatized state-owned assets through both the private and public equity capital markets. Although this has been accomplished through a series of important (and often quite creative) moves, ${ }^{79}$ we will focus on

78 This process also attracted early governance norms and pressures, not to mention more profound and significant notions of contract, enforcement of contract and law, and property rights holders' "rights."

79 The "public" and offshore side of this was achieved in four ways. First, China-domiciled issuers offered shares in newly corporatized entities to foreign, public, investors - starting with " $\mathrm{H}$ " (for Hong Kong) share off erings. For example, Shanghai Petrochemical's " $\mathrm{H}$ " shares IPO in 1993. This was followed by expanding to "N" (for New York) share offerings (Shandong Huaneng Power Development Company completed an initial public offering of ADSs on the New York Stock Exchange in August 1994), "L" (for London) share, "S" (for Singapore) shares, and so on. Second, and following from this, were the so-called "indirect" overseas listings, whereby PRC-dominated issuers were domiciled in Hong Kong or other offshore jurisdictions and issued shares on foreign markets. For example, China Telecom (which became China Mobile), CNOOC, etc., - which have issuers that are Hong Kong companies, issuing shares in the foreign (or Hong Kong) 
the net effects of these efforts. The biggest effect was to induce foreign venture capital, private equity, retail and institutional shareholders to invest in PRC-domiciled or PRC-controlled foreign (including Hong Kong and foreign tax haven-domiciled) firms.

In order to attract foreign, public equity, investors the PRC made a series of statutory, regulatory and governance changes to serve the perceived specific interests of foreign shareholders. These ranged from special statutes applicable only to foreign-invested or PRC-domiciled issuers listing overseas, to mandatory corporate constitutions for overseas-listing entities which introduced shareholder-friendly minority voting or class rights into Chinese law. As noted below, many of these items were later picked up and made applicable to all Chinese companies and purely Chinese public shareholders. In addition, so-called overseas listings brought Chinese issuers (and their shareholders, governing departments and advisers) into close contact with foreign legal and regulatory regimes - whether it was Hong Kong, New York or London. Thus, the introduction of foreign capital not only effected indigenous legal change - and brought about the first encounter with sophisticated and highly regulated foreign regimes - but also made foreign investors active in Chinese companies of every stripe, bringing along with that participation their more sophisticated governance expectations.

\section{Regulatory efforts}

Although the PRC legislature has made changes reflected in so-called "basic" laws - like the Company Law and the Securities Law - the CSRC has been the undisputed leader in reforming corporate governance more broadly. These reforms have conformed with the CSRC's authority to regulate the public markets and Chinese exchanges, and thus their work has concentrated on the corporatized SOEs permitted to list in China or abroad, and the kind of Chinese company which we identify above as the focus of China's corporate governance obsession. The efforts of the CSRC have gone some way in bringing governance to the fore and

capital markets after taking title to in-country PRC assets. Third, foreign investment was permitted in the previously walled-off " $A$ " share markets (RMB yuan denominated shares traded among PRC citizen retail investors through China's domestic exchanges) via a Qualified Foreign Institutional Investor (QFII) program. Finally, foreign, private "strategic" investment (with board designations accompanying) was permitted alongside foreign public investment, explicitly so as to introduce strong, and relatively concentrated foreign shareholder participation in business decision-making and internal firm governance. 
providing benchmarks against which investors and firms can measure themselves. This, in and of itself, is invaluable.

For example, the CSRC has: promulgated a coherent statement of Corporate Governance Principles; "recommended" (but in reality mandated) articles of association for purely domestic issuers with important elaborations of corporate governance; mandated a compulsory independent director system (requiring listed company boards to have at least a onethird "independent" board); established a veto right for "public shareholders" with respect to certain significant transactions (later incorporated into the amended Company and Securities Laws); issued rules requiring approval by disinterested persons for certain transactions; and set out qualifications for who could serve as a director of a Chinese company.

In addition, the CSRC has worked to increase the amount and relevance of mandatory disclosure by PRC companies seeking capital on the Chinese domestic markets. This served to not only make markets more transparent for shareholders, but also provided additional information for China's muckracking financial media, which revels in its relative freedom to expose continuing governance difficulties or fraud. And the CSRC has had a significant role in creating rules and transactional imperatives for public company mergers and acquisitions, going some way to creating a necessary market for corporate control in China, with attendant governance and monitoring benefits.

Finally, the CSRC has built an impressive and sophisticated enforcement bureaucracy which maintains some objectivity because the CSRC (and its local departments) are independently, and centrally, funded. (China started regulating its embryonic exchanges and securities trading via local branches of the central bank, the People's Bank of China, which were quickly co-opted by local powers or proved technically incompetent.) No doubt, the CSRC does not have the massive resources required to monitor corporate activity through China's vast hinterland. This is one reason why the CSRC above all other departments has pushed the private right of action for shareholders in China's courts so strongly. However, the enforcement function has performed admirably in the context of China's political, commercial and geographical context.

In addition to the CSRC's efforts, several years ago China ended the long-standing "quota" system governing access to listings. Regional governments used to be given a "quota" of firms they could select to list on the Chinese exchanges or on overseas exchanges. This also meant that local governments would select affiliated firms for listing and bar other, often more entrepreneurial, firms from accessing capital. Now, however, 
the opportunity to list may be available more broadly. These simple, if incremental, changes not only reduced the cronyism that persisted before, but also brought a new kind of corporation to the attention of public investors: issuers which did not have the support, or protection, of state or political actors, and who might seriously attend to profitability and performance to continue raising capital and appealing to the markets. This also would have further focused attention on firm profitability and how proclaimed and demonstrated governance might enhance it.

\section{Legal duties and obligations}

Not only has the mix of investors and the regulatory environment changed, so has the law. The radically amended Company and Securities Laws 2006 now provide, in the most explicit terms desirable, the following: (i) directors' and officers' fiduciary duties - including Anglo-American style duty of care and duty of loyalty; (ii) joint and several liability for directors, officers and supervisory board members for a broad range of violations or breaches of "law" (including the duties described in (i) above); (iii) liability of "controlling shareholders" who abuse the corporate form, or prefer their own interests to the disadvantage of minority interests; ${ }^{80}$ and (iv) increased protection for minority shareholders. ${ }^{81}$ Although many of these measures will need to rely on court enforcement (which is problematic due to lack of political power and experience with such matters), they were in many cases absent from prior "basic" enactments and are critically useful continuing steps in enhancing governance. There is in fact evidence that the People's Courts have greater competence and political power in identifying and

The heightened obligations include: greater disclosure requirements for controllers, new legal duties governing their actions, and liability for misdeeds nominally attributed to their dominated subsidiaries. It should be noted that the Company Law 2006 also introduces "veil piercing" protection for third parties dealing with PRC corporations. While not entirely workable in the short term (given the lack of sophistication and power of the judiciary), the mechanism stands as an additional warning to "tyrannical" controlling shareholders. In the context of this writing, this development is also of interest because it, once again, throws a good deal of work to the Chinese courts for articulation and resolution.

81 Protection for minority shareholders now includes cumulative voting for the election of directors (Company Law 2006, Article 106), the ability for 10\% or more of the shareholders to call a shareholders' meeting (Article 102) or a board meeting (Article 111), the ability of $3 \%$ or more of the shareholders to propose shareholders' resolutions (Article 103), mandatory shareholders meetings to approve large asset or external guaranty transactions (Article 105) (and supermajority approval for the same) (Article 122), and the ability of $10 \%$ or more of the shareholders to trigger liquidation (Article 83). 
enforcing against breaches of these key governance duties, even before the duties were finally set forth in law. ${ }^{82}$

Moreover, when this is coupled with the now completed effort to sell down the state's (or legal person's) interest in Chinese corporations which have publicly listed stock via the "stock rights allocation" (guquan fenzhi) program we can see important changes afoot. Indeed, the desire to rid the Chinese capital markets of a burdensome "overhang" of illiquid shareholdings (and thus move closer to market valuation) is only one of the purposes of this incremental sell-down. A perhaps equally important goal is to create the potential for improved governance at China's listed firms, and allow greater power or at least input for private (retail or institutional) shareholders when faced with unresponsive, conflicted or corrupt holders of non-tradeable shares.

\section{Enforcement}

The Company Law 2006 establishes the first private right of action for shareholders in Chinese companies to sue on a wide range of corporate malfeasance or breach of corporate law duties. Since China's Supreme People's Court - in response to CSRC, popular and media pressure first allowed a limited shareholders private right of action with respect to false or misleading securities disclosure in January and December 2002, this has been an issue of surpassing importance in China. Now, the Company Law 2006 provides a private right of action for shareholders to sue directors, officers and supervisory board members, directly or derivatively, and the Securities Law 2006 expands the class of potential defendants by creating joint and several liability for "controlling shareholders" or "actual control shareholders" ${ }^{83}$ where there is false or misleading disclosure in issuance-related disclosure, or continuing disclosure and reporting. ${ }^{84}$ Granted, the utility of these new rights of action remain unproven, as China awaits definitive rules from the court bureaucracy as to how litigants can actually bring such cases. However, as the creation of the all-important legal basis for private enforcement of corporate law and securities regulation, these new rights represent a huge step forward which will have much meaning in the decades to come. Of course, in the short to medium term, the crafting of these rights in law represents a keen challenge to the PRC court system, although one that is

${ }^{84}$ Securities Law 2006, Article 69 (amending the Securities Law 1999, Article 63). 
almost certain to be taken up over time under pressure from aggrieved owners of Chinese firms.

\section{Credit providers and bankruptcy constraints}

Finally, the context for external monitoring of firms by providers of credit is changing rapidly. There is a significant change under way in the way third party providers of credit - China's commercial banks - are established, capitalized, corporatized, operated, and how they monitor the use of the capital they lend. Because of these changes it is most likely that banks - over time - will become far more effective monitors of Chinese corporate performance even as they become better monitored by their owners and the public markets generally. In formal terms, the bankruptcy or hard budget constraint on Chinese firm performance has been strengthened, with the promulgation of a PRC Bankruptcy Law, which greatly empowers and protects creditors at least in formal terms. As with the private right of action to sue for corporate law and disclosure breaches, it is still too early to understand how this new Law and its attendant monitoring powers will play out over time. However that unfolds, it is important to note once again the legal basis in Chinese law for this very significant and useful mechanism for the monitoring of Chinese firms into the future.

The series of changes detailed above provide the seeds for the development of improved and more effective corporate governance in China. We also note, importantly, that these changes have not come about in isolation, but in the context of rapid and impressive institutional change and reform which comprehends: deepening involvement by non-trade foreign investors (e.g., venture capital, private equity and institutional investors rather than multinational product investors); an expanded and increasingly autonomous role for the courts (and better trained, less conflicted, politically more powerful personnel); the rise of an independent bar; and a media that has obtained some significant freedom insofar as they limit their exhortations to the financial, commercial or economic sectors. These contextual changes are necessary if some of the corporate governance changes noted above are to become anything more than merely formal, or empty and unapplied, changes in law.

\section{E. What remains to be done in China (short term)}

The short-term requirements for China's continuing corporate governance reform seem obvious, but will be constrained given political, institutional and resource limitations. We enumerate here some of these 
possible developments to further illuminate the scope of the challenge facing China's policy makers and legislators in the next decade.

It perhaps goes without saying that China's legislation and regulation will need on-going substantive elaboration and clarity. To give one narrow but critically important example, while the new declarations of "duty of care" and "duty of loyalty" in Chinese company law are laudable, it is far from clear what those concepts really mean in China, how they can be reliably described, and whether or not they will be enforceable in any real way, or even actionable given parallel systems of regulation which might prohibit actions on breach of fiduciary duties (as the Supreme People's Court presently asserts).

Consider another example. One option to solve the "absent principal" problem in Chinese firms controlled by state or state-delegated entities is to set up intermediate shareholding entities which are interested in, and operate, the enterprises they are invested in. In the financial sector, the PRC made headway in this regard by recapitalizing its technically insolvent SOE commercial banks via a new entity established by the Ministry of Finance and the PRC central bank and known as Huijin which became the dominant and controlling shareholder in China's commercial banks. Real personnel were suddenly involved in Huijin's monitoring of commercial banks and more importantly the of ten conflicted insider management at the same banks. (Huijin has since been absorbed into China's main sovereign wealth investor, China Investment Corporation (CIC), and it is open to question whether CIC will - with its far more diffuse investment portfolio in China and abroad - be able to match Huijin's record of close monitoring.) In the non-financial state assets sector, 2003 saw the establishment of something billed as a Huijin-like entity, the State-owned Assets Supervision and Administration Committee (SASAC). However, the jury is still out on the extent to which the SASAC can and will act as a real principal, or whether its monitoring capacities will be overcome by the very large number of enterprises it now controls (as compared to the four commercial banks controlled by Huijin) and it will revert to the status of another "absent" principal which has dominated the history of China SOE corporatizations.

For external monitoring, it is clear that the commercial banking industry must continue to be reformed and modernized before it will be able to resist providing capital to Chinese firms on a political rather than commercial basis. In this regard, the agreement and implementation of a complete, and sophisticated, bankruptcy regime, and a court or 
decisional system sophisticated enough to handle bankruptcy matters, is of signal importance. If ex post standards are to be applied to, and articulated for, the key actors in any governance inquiry, then the courts must find some way to increase their sophistication, political power, and enforcement capabilities prior to that part of the corporate governance system becoming workable. This is the great task of China's overall "legal construction" program.

In the institutional sphere, and especially in the absence of a strong or competent judiciary, the CSRC must continue to be supported (financially and politically) so that it can continue its unique legislative, investigative and enforcement functions. Notwithstanding that reality, those concerned with institutional reform and empowerment must continue to pay close attention to procedural changes which - one day - will allow courts to be a viable instrument in the application and enforcement of a reforming corporate governance system. For instance, the Supreme People's Court will be required to accept the broad shareholders' (or company's) right of action set forth in the Company Law 2006. It remains to be seen if the Supreme People's Court will resist - by its own administrative rules and explanations (such as the Rules on Private Shareholders Suits for False or Misleading Disclosure of December 2002) - what is now plainly authorized in a national statute promulgated by the PRC legislature. Likewise, the PRC will need to come to terms with the notion of class action litigation coupled with lawyers' contingency fee arrangements. (Note that the problem in the PRC at this point is not too many frivolous suits, but too little monitoring of the firm by shareholders and others as well as resource constraints on the CSRC limiting its ability to monitor on the shareholders' behalf.) However, the class action is relevant to the prosecution of actions in areas more sensitive than firm governance - i.e., land confiscations, labor unrest, environmental outrages, and official malfeasance in connection with health disasters. Accordingly, it may be some time before the Chinese authorities write into law a useful class action mechanism.

\section{Insights on corporate governance from China and India}

The accounts of the development of corporate governance reform in China and India may also provide insights on topical debates in corporate law scholarship. In particular, the experiences of China and India help us to examine how certain theories operate in the world's two largest emerging markets and fastest growing economies. 


\section{A. Stock market development and "legal origins"}

The question of how law might help to create better governed companies and thereby develop stock markets has captured the imagination of the academy. In their now seminal articles, La Porta, La Silanes, Schleifer and Vishny find that countries with a common law legal system tend to have more developed stock markets than countries with a civil law legal system (the "legal origins" perspective). ${ }^{85}$ They suggest at least two reasons for this. First, they argue that the common law is more protective of property rights, specifically the interests of smaller shareholders, than a civil law system. This, they assert, is bécause the common law expects judges to use application of flexible fiduciary duties principles in regulating behavior whereas the civil law is more rigid. The greater latitude granted to judges permits them to police opportunistic behavior and outright fraud more effectively than civil law courts and this is something small investors (the likely victims of such fraud and opportunism) value. Consequently, one would expect to find that jurisdictions that are part of the common law system have more developed stock markets because the common law is more protective of small shareholders and this motivates and encourages small shareholders to participate in capital markets regulated in such jurisdictions.

Another reason why "legal origins" may matter is that the civil law is said to over-regulate relative to the common law. This is important because the lighter regulatory orientation of the common law is said to facilitate private ordering (i.e., market based transactions) whereas the civil law tends to discourage such private ordering because outcomes (or perhaps processes) are determined by regulation. The more private-ordering-friendly approach of the common law is

85 Rafael La Porta, Florencio Lopez-de-Silanes, Andrei Shleifer and Robert Vishny, "Legal determinants of external finance" (1997) 52 Journal of Finance 1131; Rafael La Porta, Florencio Lopez-de-Silanes, Andrei Shleifer and Robert Vishny, "Law and finance" (1998) 106 Journal of Political Economy 11.13. Later papers have suggested that common law systems tended to outperform civil law systems both in their countries of origin (i.e., European civil law countries tended to perform worse than Anglo-American common law countries) and even in countries where they had adopted one of these approaches (i.e., the former German and French colonies performed worse on stock market development compared to former English colonies). Further studies also suggested that it was securities laws in particular that seemed to make a substantial difference in the outcomes. See Rafael La Porta, Florencio Lopez-de-Silanes and Andrei Shleifer, "What works in securities laws" (2006) 61(1) Journal of Finance 1-32. 
important because securities markets tend to thrive in such marketfriendly environments. ${ }^{86}$

Although these papers have been highly influential, there has been considerable discussion of alternative views. In particular, a series of papers from both economists and legal academics suggest that "legal origin" is not the primary explanation for why we tend to see common law countries with better governed firms and thus more developed stock markets. ${ }^{87}$

These other papers first suggest that the descriptions of common law and civil law oversimplify reality and that in many instances so-called common law countries have even more regulation bias than civil law countries. ${ }^{88}$ Indeed, both systems - as seen in developed economies seem quite adept at being able to use (or borrow) tools and techniques from the other. Second, these papers suggest that the growth of stock markets is better explained by three other factors. First, that there is demand for what stock markets can provide - external capital. This has tended to be the case when economic or technological changes require the aggregation of capital from many sources and there is no really good alternative to stock markets. Second, the institutions that support stock markets are in place or are being put in place by legislators or private ordering. Such institutions and practices include such staples as functioning (and independent) courts, adequate disclosure requirements, and effective methods of containing self-dealing. ${ }^{89}$ Third, the general

One might also interpret the "over-regulation" in the civil law as being regulation that benefits incumbents by making entry into domestic markets more difficult. This serves to weaken one of the other primary constraints on managers (and factors pushing toward better governance) - product market competition - because when firms face less competition then the consequences of their inefficient governance choices take longer to be visited upon them. By weakening the impetus for better governance from the product markets, civil law might tend to reinforce inefficiencies in governance and thereby also be a less attractive place for small shareholders to invest.

87 Raghuram G. Rajan and Luigi Zingales, "The great reversals: The politics of financial development in the twentieth century" (2003) 69 Journal of Financial Economics 5; Mark J. Roe, "Legal origins and stock markets in the twentieth century" (2006) 120(2) Harvard Law Review 460-527. Even some papers in the "legal origins" literature seem to suggest it is statutory securities laws (rather than judicially enforced common law) that seems to spur stock market development. This suggests "legal origins" are not after all determinative. See La Porta, et al., "What works in securities laws."

88 Roe, "Legal origins and stock markets."

${ }^{89}$ Black, "The core institutions"; John C. Coffee, Jr., "The future as history: The prospects for global convergence in corporate governance and its implications" (1998-9) 93 Northwestern University Law Review 641; John C. Coffee, Jr., "Racing towards the top?: The impact of cross-listings and stock market competition on international corporate governance" (2002) 102 Columbia Law Review 1757. 
political environment of a particular jurisdiction is deemed conducive to (or, at least, will not thwart) the growth of stock markets. ${ }^{90}$

Although the latter account summarized immediately above is more complex than the "legal origins" account, its adherents suggest that it better explains the actual development of stock markets over the last 100 years or so. Indeed, it appears that the asserted connection between common law structures and stock market development is of relatively recent origin. In the early 1900s civil law countries had at least as well developed, if not better developed, stock markets than common law countries. Moreover, in terms of stock market development, it was only after World War II that common law countries seemed to climb above civil law countries and even that trend seems somewhat short lived as the gap between civil and common law countries has diminished in recent times. This suggests, as Rajan and Zingales point out, that time-invariant structural explanations (e.g., "legal origins") cannot explain what we have seen over the last hundred years.

The question then becomes: what does explain the experience with corporate governance and stock market development over the last hundred years? Although clearly the absence of certain critical institutions (e.g., functioning courts) would retard progress in improved corporate governance and developing stock markets, many commentators focus on whether there is the political will to create responsibly governed corporate entities and develop healthy capital markets. The implicit (and sometimes explicit) assertion is that if there is the national political will then there is a political (and economic, legal and institutional) way.

Rajan and Zingales suggest that, normally, incumbents will oppose stock market development because it provides easier access to capital for new entrants and hence enhances competition for those incumbent firms. However, incumbents may be willing to support such development if they also need access to external capital to take advantage of perceived business opportunities and there is no other viable source of such external capital besides functioning securities markets. Thus, Rajan and Zingales suggest that stock markets may obtain popular support once incumbents also have a desire to access external capital. This is, of course, more likely in an expanding trade and investment environment, or when trade and investment is more open. Trade was indeed more

90 Rajan and Zingales, "The great reversal"; Roe, "Legal origins and stock markets." 
open before World War II and after the 1980s, and that is precisely when we see stock markets growing in many different jurisdictions. ${ }^{91}$

Although trade policy is important, Roe suggests another important historical factor: that the economic and political devastation wrought on many countries by World War II may have led their polities to become less "friendly" to stock markets in the aftermath of such destruction. He argues that after World War II in Europe many nations had few resources, and the citizenry had few savings. In such an environment the polity is more likely to focus on labor rather than investment interests, as few people have any savings to invest. Moreover, in much of Europe there was an on-going political and ideological battle against the ideological and material attractions of Communism. In order to maintain the support of the citizenry for market-oriented economies, national legislatures may have tended to favor labor. The consequence for not doing so might have triggered political reversal and a move towards Communism. This, Roe suggests, provides a better explanation for why so many countries in Continental Europe adopted less shareholder-friendly laws and tended to favor labor in the early post-War years. Indeed, this provides a good explanation for why these countries may have been averse to free trade and preferred more "protectionist" policies. On the other hand, countries that were not as badly devastated in World War II and that were further away from the front-line ideological battle over Communism (the US, Switzerland, UK) were in a better position to support stock markets oriented away from labor and toward investors. The polity in these countries had relatively more savings and thus investment resources and, one might imagine, would have been keen to pursue investment policies and probably more open trade. Once the polities in Continental Europe had savings and investment capacity, a change in the approach to stock markets might be seen, with their becoming more favored. ${ }^{92}$

Adherents to this account (we call it the "politics" account) suggest their explanations gel better with the experience of the last hundred years.

91 Rajan and Zingales, "The great reversal." Rajan and Zingales do not fully reject the "legal origins" account. Rather they suggest that the "politics" account and the "origins" account may work together in some ways, In particular, they suggest that in the civil law, being more centralized than the common law, it may be easier for private interests to have their agenda enacted (they need only convince the legislature not courts and so forth). If so, then when the political will is present for change it may occur more quickly in civil law countries than common law. They find evidence of this in how quickly the civil law was able to slow down its stock markets and how quickly it was able to speed up the development of its stock markets later as compared to common law countries.

92 Roe, "Legal Origins and Stock Markets." 
The policy prescriptions emanating from this account are more contextual. In the case of a given country one would need to understand whether the polity was supportive of stock markets and then devise legal policy in light of that to help build the institutions needed for well functioning stock markets. If the polity was not supportive then widespread reform could not proceed without first having measures to obtain support from the polity.

Both the "legal origins" and "politics" accounts provide predictions for what will lead to stock market development, but neither has been applied in significant detail to the experiences in either of the two largest emerging markets - India and China. What does our disćussion of corporate governance reform and the establishment of functioning capital markets in India and China suggest?

On a quick glance the different experiences of India and China appear to provide some support to both accounts, but looks can be deceiving. First, let us examine the "legal origins" account. Most observers will understand India as a nation firmly in the common law tradition, and China in the twentieth and twenty-first centuries closer to a civil law jurisdiction. Further, the growth of India's stock markets over the long term has been more positive and less volatile than China's, even though China has, for much of the last twenty years, experienced a higher economic growth rate than India. This, on cursory inspection, provides some support to the "legal origins" account. However, one needs to look more closely before coming to firm conclusions.

Although, India does have a common law system, for most of the period following independence (1947-91) it followed a socialist development path with policies that significantly impeded the growth of its stock markets. Many people would have easily described India as being over-regulated (the "license raj" epithet comes to mind), ${ }^{93}$ which is one of the major supposed vices of the civil law.

Moreover, the description provided in subsection III.B suggests that the background law - while apparently protective of small shareholders as it was based on English Law - was not, in reality, very protective of smaller shareholders. India's judiciary, although independent and arguably one of the most powerful in the world, did not appear to be active,

93 See Tarun Khanna and Krishna Palepu "The evolution of concentrated ownership in India: Broad patterns and a history of the Indian software industry," in Randall K. Morck (ed.), A History of Corporate Governance around the World (University of Chicago Press, 2005), pp. 283-324; Goswami, "India: The tide." 
prompt and flexible in protecting shareholders interests. ${ }^{94}$ Thus, India, while nominally a "common law" country, was performing like a civil law country on the dimensions that matter most under the "legal origins" account - protecting small shareholders and being less regulated than civil law.

One might respond by saying that we should then categorize India as something closer to a civil law-family nation (although this is contrary to how the "legal origins" literature normally categorizes). But what then explains the considerably better performance of Indian stock markets over the long term? Perhaps the answer is that India is now adopting a more common law style in terms of protecting small investors and regulating less. This is only partially true. India is certainly protecting small investors more than it has before. However, it is not necessarily regulating less, it is just changing its domain of regulation away from a direct mechanism - licenses to enter business - to indirect regulation featuring mandated disclosure and corporate governance features.

China's legal system is a different case because it partakes of different traditions or "origins" - all at the same time - in different sectors of application (e.g., Soviet and European civil law heritage in criminal law and procedure, German civil law (via Japan and Taiwan) in commercial and contract law, and the Anglo-American tradition in recent corporate and securities law (with an occasional entanglement with an inflexible "business regulation" orientation). Thus, divining a connection between legal origin, corporate governance and stock market growth in China is not a straightforward exercise. In China's reform experience, corporatization and domestic exchanges were permitted first as a politically attractive and relatively costless method of financing state-owned (and controlled) assets ${ }^{95}$ and as a substitute for direct state allocations of capital. As a result, China's enactments cleaved very closely to a business regulation orientation, or one that enabled the creation of viable financing vehicles, with little regard for the rights and interests of

94 See Debroy, "Some issues in law reform in India"; C. D. Cunningham, "The world's most powerful court: Finding the roots of India's public interest litigation revolution in the Hussainara Khatoon prisoners case," in S. P. Sathe and S. Narayan (eds.), Liberty, Equality and Justice: Struggles for a New Social Order (Lucknow, India: Eastern Book Company, 2003), pp. 83-96; Susan Thomas, "How the financial sector in India was reformed," in S. Narayan (ed.), Documenting Reforms: Case Studies from India (New Delhi: Macmillan, 2006).

95 Although China had some history with the corporate form from the end of the Qing Dynasty (to 1911), and even domestic exchanges in the Shanghai International Concession and other places before World War II, the reappearance of these norms and institutions in the late 1980s and early 1990s was in the context of no related legal tradition. 
minority shareholders. Indeed, China initially rejected the AngloAmerican model in formal terms. The current interest in protection of minority rights, and more broadly good corporate governance, has come from the sometimes bitter diet of fraud, oppression and opportunism forced onto such rights holders. This in turn has spurred concerns for political stability and the general viability, reputation and health of China's domestic capital markets. It is these concerns that have caused China's policy and lawmakers, and regulators, to look to the AngloAmerican models for a pre-packaged aid menu. ${ }^{96}$

One can also examine the "politics" account. Recall that according to this account stock market development starts with demand for external capital, the presence of supportive institutions and the political will to have strong stock markets (which is less likely after a devastating war or when the country is having an ideological battle with Communism). Here we obtain some greater traction.

In the case of China it is fairly clear that by 1949, after the AntiJapanese War, World War II and the Chinese Civil War, its domestic economy was devastated. It seems unsurprising therefore that China's new Communist rulers would, apart from ideological reasons, implement a centralized, planned, and state-owned economy rhetorically committed to the interests of "labor" and protective against imperialist economic powers. This much seems consistent with the "politics" account. However, very serious disruption continued in China for quite some time - through the Anti-Rightist Campaign, the Great Leap Forward and the start of the Great Proletarian Cultural Revolution until greater stability (and legitimacy for the Party) arose after the winding down of the most violent period of the Cultural Revolution in the late 1970s. After this level of chaos one might have expected a greater

96 The story behind the absorption of fiduciary duties into China's Company Law 2006 is illustrative of this: China's first national Company Law (1994) was very heavy on business regulation and aspirational commands; more importantly, the statute contained only very oblique references to what might be construed as fiduciary duties for directors, managers and supervisory board members. When queried on this, most Chinese academics, regulators and practitioners, justified the rejection of Anglo-American concepts with ringing calls about China's adherence to the Japanese (and incidentally Taiwanese), "Asian" and even "Confucian" traditions. Some of the abuses described, caused Chinese lawmakers to import, via direct translation, specific duties of care, loyalty and good faith into the Company Law 2006, even without any strong notion as to the viability of court articulation of enforcement of the same (and absolutely no thought that such courts were acting or would be acting in a "common" or "civil" law tradition). See Howson, "The doctrine that dared not speak its name." 
focus on labor, rather than capital. Somewhat surprisingly then, China's policy makers adopted a new strategy of economic revitalization (through experimental and ideologically incorrect marketization strategies) and the attraction of foreign capital and trade. Moreover, when the demand for external capital became great enough we witnessed a thaw in the attitude towards some notions of property and enforceable rule of law. When that same interest in capital attraction - Chinese and foreign - grew in the 1980s, there became only increasing awareness of the need to protect shareholders interests so as to attract equity investors in newly corporatized Chinese entities, and then develop strong stock markets. This account seems somewhat conflicted from a "politics" perspective. Economic reconstruction and post-trauma social instability and a desire to favor capital. However, it seems clear that in China the ability to bring about economic growth (which required capital) was one of the critical elements the Party needed to maintain political power. Thus, here we see a polity interested in economic growth (after a long period of economically poor performance) - albeit to serve political ends - that led to reforms specifically designed to attract capital.

The broader point is that the "politics" perspective - and in particular the changing political, reconstruction and stabilization needs of China over time - do seem to explain increasing awareness and implementation of new corporate governance solutions and the development of stock markets. In short, this might lead us to conclude that modern corporate governance reform in China is not only desired and delivered to serve investor expectations (and an ever more useful capital markets), but is "permitted" by a developing historical-political circumstance. ${ }^{97}$

In the case of India, World War II did not wreak the same level of domestic devastation. However English colonial rule, the difficult process of Independence and the tragedy of Partition of the Sub-Continent, among other things, seriously weakened the economic base within India. The effects of this devastation, although not identical to those of a war, likely had a somewhat similar effect on savings. Moreover, the political

97 We should note that the Chinese system has not completely abandoned the rhetoric of the first solutions required by politics, history and ideology. This can be seen in the ongoing debate about the extent to which the law should protect private property or Socialist property, the real nervousness surrounding selling down the state's interest in newly corporatized entities, and "social" or "labor" model aspects of China's corporate statutes. (On the latter issue, we point to the quickly atrophying "supervisory board" mandated at Chinese companies - now given a new lease on life under the Company Law 2006 as the recipient of shareholders' demands in the event of proposed derivative suits.) 
movement in India that led to the withdrawal/removal of the British Raj relied on obtaining something like consensus within India's vast and highly heterogenous population. This frequently involved the use of strikes and other measures that unified labor. This, one might imagine, led to the perception (accurate or not) that the polity was more favorable towards labor than capital.

However, once there was liberalization, greater international trade, and competitive spaces opened up, the demand for external capital was high. Indeed, in India industry pushed for corporate governance reform in order to attract external capital. The response was as described in subsection III.C and was embodied in a rather quick reform effort. This seems broadly consistent with the "politics" account: start with labor-oriented policies after a severe economic weakening and then as the economy grows and external capital becomes more attractive we see changes toward a more capital-friendly environment.

The experiences of India and China, however, also suggest a broadening of the "politics" account. First, the experience of India suggests that it need not only be war that leads to a change (e.g., capital-friendly to labor-friendly). Any kind of devastation of the economy (e.g., colonial policies) is likely to lead to such a change. Second, the experience of China suggests that change following devastation depends on what the status quo was before the change. ${ }^{98}$ In the case of most Continental European nations and India the devastation occurred under governments that were generally more market-friendly. In this situation the change was away from market-friendly to more labor-friendly policies. In China, however, the devastation culminated during the rule of a government that, in theory, favored labor and was actively hostile to capital investors. In this context, the final post-devastation approach (if we see the devastation as something lasting to 1976 and the death of Mao) was the opposite - more capital-friendly. This suggests, tentatively, that the change around the time of devastation may not be simply towards labor, but depends on what kind of regime preceded the devastation, and, perhaps most importantly, the political goals of the post-devastation regime.

98 In India one might view the 1991 financial crisis as the turning point for reforms. Although no doubt true, one can hardly describe the 1991 financial crisis as a "devastation." Moreover, India's growth post-Independence has not been stellar, but it can hardly be described as being analogous to what happened in China between the mid-1930s and the late 1970s. 


\section{B. Convergence and to what?}

Another important and related debate in corporate law academia is whether corporate law will eventually converge onto a particular model (e.g., the Anglo-American model based on dispersed ownership, the separation of ownership and control, application of flexible legal standards ex post). Views differ considerably on whether convergence is likely to happen and, if it does, whether it will be formal convergence (the laws look very similar) or functional convergence (the laws are different but achieve the same functions) or some intermediate point.

The formal convergence argument was most recently articulated by Hansmann and Kraakman where they argue that formal convergence is likely (or already happening) because (i) the shareholder primacy view of corporate law (i.e., managers owe duties to maximize shareholder wealth) has trumped other views, (ii) the competition of the global market place in particular the global competition for capital, but also product markets competition - will lead firms and nations to choose the Anglo-American model of corporate governance, and (iii) that there is now a shift of interest groups in favor of an emerging class of shareholders. Although all three parts are important to the formal convergence argument, many commentators have focused on prong (iv) because of the perception that competition in the product and capital markets will force firms with different governance structures to compete with each other. ${ }^{99}$

The implication is that Darwinian competition will lead to the success of the Anglo-American model as it is more suited to capital-raising than other models, and because access to capital may be a significant factor in obtaining success in product and other markets. This is especially significant for newer firms and industries, not to mention new entrants from emerging markets. Moreover, as the speed of innovation increases we might expect the newer firms to become more important and dominant in each country.

99 There is debate over whether the shareholder primacy account has truly won out. See Lynn Stout, "Bad and not-so-bad arguments for shareholder primacy" (2002) 85 Southern California Law Review 1189; Kraakman and Hansmann. "The end of history for corporate law". However, for purposes of analysis we assume that it has won out to examine how competition in product and capital markets might influence the selection of corporate laws and institutions. Further, the interest groups supporting the shareholder class are interesting because often these groups are pension plans and unions which represent labor. Labor and capital are then interlinked, rather than opposing, forces in this account. 
The primary alternative to the formal convergence account is the "path dependent" account. Under this view, corporate laws are much less likely to converge onto a single model because aspects like ownership structure and corporate rules are much less amenable to change than one might think. Bebchuk and Roe argue that rules can be path dependent for both efficiency reasons, as well as rent-seeking (i.e., inefficient) reasons. ${ }^{100}$

Rules can be efficiently path dependent because the background institutional structure may be too costly to change and hence only some rules (i.e., the path dependent ones) are worth pursuing. If so, then the fact that the rules are not the same as the Anglo-American model may not be inefficient given the costs of institutional change in a particular country. Rules can also be inefficiently path dependent because parties who benefit (i.e., incumbents) under the pre-existing structure may lobby effectively to block change, even when it is efficient overall, because it reduces their gains. Such rent-seeking may lead to inefficient and path dependent results. Regardless of the source of path dependent rules, their presence (and the difficulty and cost of changing the background institutional structure) is likely to impede convergence.

Of course, neither side is suggesting clearly defined outcomes. The path dependency advocates would probably accept that if the advantages of change are sufficiently (and perhaps overwhelmingly) large then even the costs associated with change can be overcome. Further, the convergence advocates do not predict that governance rules will converge overnight. Thus, one could view the convergence and path dependent camps as occupying two points on a continuum assessing how fast, and how much, change might occur: the convergence advocates would suggest quickly and the path dependent advocates would suggest slowly, if at all. Moreover, if convergence will take time then it is possible that even the countries currently using the Anglo-American model may not be using it in fifty years (e.g., serious economic downturn in that country leading to the adoption of more socialist policies). Thus, by the time one country has adopted the Anglo-American model it is possible that countries that used to employ it do not any more - making it difficult to describe this process as convergence. The critical matter then is whether the forces for convergence (e.g., product and capital market

100 Lucian A. Bebchuk and Mark J. Roe, "A theory of path dependence in corporate ownership and governance" (1999) 52 Stanford Law Review 127. 
competition) will move quickly enough to overcome the forces of path dependency (e.g., entrenched interests and institutions, high costs associated with change).

Finally, some have suggested intermediate accounts of legal change in the corporate arena. Gilson suggests that corporate law rules may tend towards functional convergence rather than formal convergence. The competitive forces that make the Anglo-American model attractive may lead many firms and countries to want the advantages this brings (e.g., more capital, better products), but the cost to changing all the institutions may be too high or take too long. ${ }^{101}$ So instead of changing all institutions to mimic the Anglo-American model, countries and firms may make changes that have the same effects as the Anglo-American model (e.g., protecting minority shareholders, enhanced disclosure), but in form are still similar to the pre-existing rules which were not in conformity with the Anglo-American model. This provides, Gilson argues, most of the benefits of the Anglo-American model while not implicating the huge costs of formal change. This might be termed the "path of least resistance" or "path of greatest convenience" approach.

Coffee also suggests an intermediate account where a firm can specifically enhance its capital raising abilities by simply listing on, and meeting the requirements of, a foreign securities exchange. ${ }^{102}$ In some respects the firm is borrowing the apparently better disclosure, accounting and governance requirements of the foreign securities exchange to enhance its image in the eyes of potential investors, whether from the same country or abroad. Of course, this is a partial solution as some elements of the regulatory regime imposed by virtue of the foreign exchange listing may not be credible in the country from which the firm emanates. Nonetheless, such listings may help individual firms.

In light of these differing theories on convergence, what can we learn by examining India and China? The experiences of India and China throw light on the issue of convergence because both countries face intense product and capital market competition (sometimes with each other), but they have long histories with strong interests and powerful, pre-existing, institutions. The countervailing forces - competition for convergence and institutional strength behind path dependence provide an interesting testing ground for the convergence debate.

101 Ronald J. Gilson, "Globalizing corporate governance: Convergence of form or function" (2001) 49 American Journal of Comparative Law 329.

102 Coffee, "The future as history"; Coffee, "Racing towards the top?" 
Overall, we do see some trends toward convergence, but it is unclear how fast they will develop and the extent to which they will mimic the Anglo-American model or something else. For example, in India and China over the last decade we see greater protections for minority shareholders, increased customization, independence requirements, enhanced disclosure, more expectations of the board and audit committee for monitoring and increased obligations on executives. These all seem consistent with the Anglo-American model for dispersedly held corporations.

However, controlled (not dispersedly held) firms are still the most important and frequent players on the major Indian and Chinese exchanges. This is true even though many of the top corporations on the exchanges are relatively new players in the field. This suggests only partial convergence has occurred so far. The law is converging, but the corporations are still largely controlled not widely held.

Further, the reforms in the Indian equity markets have progressed much faster than similar reforms in the Indian debt markets. Even now, the Indian corporate bonds markets are weak and insolvency laws painfully slow. ${ }^{103}$ This reflects the political balance in India as it relates to debt and insolvency where labor interests are much more likely to block significant reforms in this sphere than in the equity sphere. ${ }^{104}$ This suggests that - at least on the debt side - there are serious path dependencies at work. What impact this will have on convergence in governance reforms on the equity side is still to be seen.

In China, we witness a rather complex set of developments. There seems little doubt that a kind of "convergence" can be identified with respect to China's corporate governance and securities regulation norms. China's earliest incursions into corporate governance reform occurred under the protection of (then) Vice Premier Zhu Rongji and were in large part driven by a unique generation of "returned from abroad" (haigui) individuals who had received graduate-level law training in the United States and to a lesser extent the UK and Commonwealth countries. Once corporatization and the establishment of stock exchanges became politically more palatable, these individuals implemented a

103 See Jennifer Asuncion-Mund, “India's capital markets: Unlocking the door to future growth," Deutsche Bank Research Paper, February 14, 2007.

104 See Madhukar R. Umarji, "Trends and developments in insolvency systems and risk management: The experience of India," working paper (2004); Vijay Joshi and I. M. D. Little, India's Economic Reforms 1991-2001 (Oxford: Clarendon Press, 1996); S. Thomas, "How the financial sector in India was reformed." 
system closely patterned on what they had seen in more developed, foreign markets or, where they were unable to, they adjusted the laws to suit the specific needs of overseas investors. ${ }^{105}$ Some of this initial convergence was frustrated or even reversed when both the Company Law 1994 and to a much lesser extent the Securities Law 1999 were captured by more conservative drafting groups and superseded earlier regulations. ${ }^{106}$ Perhaps more pernicious in the frustration of convergence was the stubborn capital structure of SOEs corporatized as companies limited by shares. As has been noted widely, China's new corporations continued to be owned at a level of $70-80 \%$ by former state bureaus or local government actors. Thus, we have witnessed adoption of legal forms suitable to the AngloAmerican model of the dispersedly held firm, but the actual firms still remain controlled rather than widely dispersed. We do not at this stage speculate as to why the PRC adopted a formally (not functionally) convergent corporate law, aside from the obvious reason that they could do it and still attract vast infusions of capital - foreign and domestic - to prop up and then expand failing SOEs.

Yet an important fact is the on-going, and far more realistic functional, corporate governance reform in China (e.g., substantive changes in the Company Law, provision for shareholder suits on corporate breaches, establishment of an independent directors system, an increasingly activist and independent financial media, and diluting the state/ legal person dominance at PRC issuers to create more widely dispersed capital structures). Some might ascribe the impetus for these changes to the requirements of foreign investors and foreign regulatory systems, but that is a simplistic view. ${ }^{107}$ It disregards the purely indigenous aspect of

105 The 1993 promise by the now def unct Commission for Reform of the Economic System to the Hong Kong Stock Exchange that a form of words in the 1992 Opinion on Standards for Companies Limited by Shares governing PRC issuers to Hong Kong had the same meaning (and presumably effect) as the entire jurisprudence of "fiduciary duty" under Hong Kong law is a remarkable demonstration of this fact.

106 For instance, the Company Law 1994 contained a nonsensical Article 4 which maintained that state shareholders continued to own, directly, state assets contributed to the corporation, effectively looking right through the intervening corporate entity. By the same token, the Company Law 1994 was replete with special provisions for what were SOEs, in all but name, including the troublesome creation of a "wholly state owned corporation" with no shareholders, no shareholders' meeting, but a board of directors appointed by the state department "owning" the company.

107 It would also disregard the surprising fact that many purportedly sophisticated investors and portfolio managers continue to throw money at China's newly corporatized issuers regardless of the form or function of corporate governance, or the listing domicile, seemingly unable to miss a ride on the China "growth story." 
the push for corporatization and better corporate governance at China's enterprises: Chinese forces which want better governed and more efficient firms, policy makers who want healthier capital markets, regulators who want better markets and a "just" result for participants damaged by fraud, shareholders who want remedies or compensation, and the legal reform constituency which has a long-term "rule of law" agenda which it thinks can be implemented first in the corporate and commercial sector. The point is that China may now be moving past a period of formal-notfunctional convergence into functional (and sometimes formal) convergence, and for reasons not directly related to the assumed requirements of foreign external finance. This in turn may cause us to query why the PRC has consistently chosen the "shareholder oriented" model of business organization, a disclosure-based securities regulatory structure, and the beginnings of a private enforcement mechanism (as an adjunct to outright business regulation) - all in a world where everyone seems to admit that property rights are weak, the business regulation tradition is weak, the courts are still deficient, and China has no experience with (or interest in allowing for) enterprises with widely dispersed shareholding.

Indeed, when looking at both India and China one question constantly occurs: why have both countries adopted Anglo-American style corporate and securities law reforms - generally thought to be most suitable for widely held (Berle and Means described) firms - when neither country has seemed enthusiastic about encouraging such widely held firms in either new or old industrial sectors? Rather, both countries continue with largely controlled firms (though there are more new dispersedly held Indian firms than before), and even some re-consolidation of previously devolved entities (e.g., in China's aviation and power generation sectors). Even the firms from India and China that list on foreign exchanges are generally controlled firms. Moreover, at least for Indian firms these foreign securities exchanges are not their primary source of capital; for China, this is also becoming true, as even many of the solely offshore-listed (including Hong Kong SAR-listed) firms are returning to the Shanghai Exchange for large, follow-on, RMB yuan financings. Rather, such cross-listings appear more and more designed to provide comfort to the likely "products markets" customers of the Indian and Chinese firms - US and European firms.

One explanation may be that convergence is in the early stages in both countries. It may simply be that the laws are relatively new and that it will take some time for dispersed shareholdings to become more common or 
politically palatable. However, both countries have been engaged in corporate governance reforms for more than a decade and one wonders why newer firms have not sought more dispersed capital structures under the umbrella of legal and regulatory systems which would seem to lead them to the same. Of course, there is yet a broader question - why have adopted reforms aimed at one type of firm (widely held) been fairly successful at raising capital for different kinds of firms (controlled)? One could speculate that this is because the market is not responding as one might expect or the reforms are simply signals to investors about what to expect (i.e., better governance) or that some elements of laws designed for widely held firms also help to reduce problems with controlled firms.

\section{Conclusion}

China and India are the new economic juggernauts. Both countries have experienced phenomenal growth and dramatic interest from foreign investors. Both have survived the Global Financial Crisis 2008-9 in far better shape than most of their developed-world competitors. Indeed, the efforts of both countries to reform their corporate and securities laws to attract foreign and domestic investors and develop stock markets have been front page news. In this chapter we have explored how these reforms have come about and what we might learn from them. Although both countries have many differences, we suggest that the similarities rapid economic development, significant private and public foreign investment, economic and structural reform, booming stock markets and a shared interest (if not implementation) in "formal" Anglo-American corporate law norms - provide an interesting and rich platform for consideration of contested corporate governance and corporate governance reform issues.

In order to explore these issues we began by briefly providing some political, economic and legal background for both China and India and then discussing their corporate governance reform efforts. Both countries have emerged from less market-oriented economic and regulatory systems to world-shaking economic reform programs, resulting in huge growth, the development of domestic capital markets and dominant participation in the global capital and product markets. And, in the case of each nation, this change has been matched by widely proclaimed corporate governance reform. Our central question revolves around the connection between the obvious developments in China and India, and the corporate governance reforms in both countries. When we 
evaluate the experiences of these two economic juggernauts and try to apply them to corporate governance theories, we can gain interesting insights. In particular, both countries' experiences suggest that the "legal origins" account does not provide the best explanation for the development of their respective corporate governance templates or domestic capital markets. Rather, a nuanced politics "account" provides greater explanatory power, especially when we try to understand the true effects of difficult and ultimately dislocating historical circumstances like India's Independence, English Colonial Rule and the trauma of Partition, and China's very difficult twentieth century at least to the end of Maoist rule in 1976. As noted in this chapter, both countries appear to have adopted, or are adopting, Anglo-American style corporate governance forms and reforms, yet most of the significant firms domiciled inside these nations (listed or not) remain stubbornly controlled. Thus, more than a decade after radical reform, the capital structure of China and India's corporations remains as it was: subject to overwhelming control by one or a group of connected and often politically powerful shareholders. Thus, perhaps the greatest puzzle raised by this initial inquiry is the fate and future of these corporate establishments - will they change to meet the structures assumed under the received AngloAmerican models of corporate governance and securities regulation? If they do not change, how is it that a legal and regulatory strategy designed for different kinds of corporate entities and investor populations can continue to benefit the development of viable stock markets? These questions become increasingly important, not just for corporate governance specialists, as the world watches the rise of India and China in the global capital and product markets. 


\begin{tabular}{|c|c|c|}
\hline Characteristic & Clause 49 & J. J. Irani Committee \\
\hline Independence & $\begin{array}{l}\text { - Requirement - } 50 \% \text { independent directors } \\
\text { if Chairman is executive director or } 33 \% \text { if } \\
\text { Chairman is not. } \\
\text { - Definition - not related to Board or one level } \\
\text { below Board and audit partners must have no } \\
\text { prior relationship with the Company for the } \\
\text { last } 3 \text { years. } \\
\text { - "Material" - There is no requirement for the } \\
\text { relationship to be "material." } \\
\text { - Financial institutions - are considered } \\
\text { independent. }\end{array}$ & $\begin{array}{l}\text { - Requirement-33\% for companies with public } \\
\text { interest. } \\
\text { - Definition - not related to employees of the } \\
\text { Company and no prior relationship with the } \\
\text { Company for one year. } \\
\text { - "Material" - board to review what is "mater- } \\
\text { ial" on an on-going basis. } \\
\text { - Financial institutions - not considered } \\
\text { independent. }\end{array}$ \\
\hline $\begin{array}{l}\text { Board requirements } \\
\text { \& limitations }\end{array}$ & $\begin{array}{l}\text { - Meet } 4 \text { times a year (maximum gap of } 3 \\
\text { months between meetings). } \\
\text { - Limits on number of committees a director can } \\
\text { be on (10), but only } 5 \text { for which director can be } \\
\text { Chair of committee } \\
\text { - Develop Code of Conduct. }\end{array}$ & $\begin{array}{l}\text { - Meet } 4 \text { times a year (maximum gap of } \\
4 \text { months between meetings). } \\
\text { - Limits of number of directorships (15). }\end{array}$ \\
\hline $\begin{array}{l}\text { Audit Committee } \\
\text { composition }\end{array}$ & $\begin{array}{l}\text { - At least } 3 \text { directors (two-thirds must be } \\
\text { independent). } \\
\text { - All financially literate. } \\
\text { - At least one having accounting or financial } \\
\text { management experience. }\end{array}$ & $\begin{array}{l}\text { - No minimum number of directors (majority } \\
\text { need to be independent). } \\
\text { - No requirements for financial literacy. } \\
\text { - At least one should have accounting/financial } \\
\text { management knowledge. }\end{array}$ \\
\hline
\end{tabular}




\section{Audit Committee role and powers}

Disclosures

\section{Certifications}

\section{Subsidiary}

Companies
- Audit Committee Meetings - 4 meetings (gap between meetings not exceed 4 months).

- Audit Committee role is broad - review statutory and internal auditors as well as internal audit function.

- Related party transactions

- Accounting treatments and departures

- Risk management

- Proceeds from offerings

- Compensation for directors (including nonexecutives and obtain shareholders' approval)

- Details of compliance history for last 3 years

- Corporate governance reports (and disclose adoption, if any, of mandatory and non-mandatory requirements)

- CEO \& CFO:

- financial statements

- effectiveness of internal controls

- legal transactions

- inform audit committee of any significant changes in the above.

- Auditor or Company Secretary:

- Compliance with corporate governance

- At least one Independent director of Holding Company should sit as a director on Board of material non-listed Indian subsidiary.
- Audit Committee Meetings - number not specified.

- Related party transactions

- Executive compensation

- Unusual transactions

- Director's background
- CEO, CFO \& Company Secretary

- financials

- CEO and CFO:

- internal controls

(with audit committee approval) 
Appendix 15.1 (cont.)

\begin{tabular}{ll}
\hline Characteristic & Clause 49 \\
\hline & - Significant transactions report to Holding
\end{tabular}
company Board (along with subsidiary board's minutes).

\section{Other}

- Whistleblower policy is optional.

- Independent directors lose status as "independent" if served 9 years at company.

\section{J. J. Irani Committee}

- Training board members.

- Evaluate non-executive board performance.

- Whistleblower policy and protection for whistleblower is encouraged. 


\section{References}

Anant, T. C. A. and Goswami, Omkar, "Getting everything wrong: India's policies regarding 'sick' firms," in Dilip Mookherjee (ed.), Indian Industries: Policies and Performance (Delhi: Oxford University Press, 1995)

Asuncion-Mund, Jennifer "India's capital markets: Unlocking the door to future growth," Deutsche Bank Research Paper, February 14, 2007

Bagchi, A. K., Private Investment in India: 1900-1939 (Cambridge University Press, 1972)

Bebchuk, Lucian A. and Mark J. Roe, "A theory of path dependence in corporate ownership and governance" (1999) 52 Stanford Law Review

Bhattacharyya, Asish K. and Rao, Sadhalaxmi Vivek, "Economic impact of 'regulation on corporate governance': Evidence from India," Indian Institute of Management Calcutta Working Paper No. 486/2004, January 17, 2004 (2005), available at http://129.3.20.41/eps/fin/papers/0504/0504002.pdf

Birla, Shri Kumar Mangala, Report of the Committee Appointed by the SEBI on Corporate Governance under the Chairmanship of Shri Kumar Mangala Birla (1999)

Black, Bernard S., "The core institutions that support strong securities markets" (2000) 55 Business Lawyer 7

Black, Bernard S. and Kraakman, Reinier H., "A self-enforcing model of corporate law" (1996) 109 Harvard Law Review 1911

Chakrabarti, Rajesh, The Finacial Sector in India: Emerging Issues (New Delhi; New York: Oxford University Press, 2006)

Chunying, Xin, "What kind of judicial power does China need?" (2003) 1(1) International Journal of Constitutional Law 58

Clarke, Donald C., "Power and politics in the Chinese court system: The enforcement of civil judgments" (1996) 10 Columbia Journal of Asian Law 1

"Corporate governance in China: An overview" (2003) 14 China Economic Review 494

Chan, Wellington K. K., Merchants, Mandarins and Modern Enterprise in Late Ch'ing China (Cambridge MA: East Asian Research Center; Harvard University Press, 1997)

Coffee, John C., Jr., "The future as history: The prospects for global convergence in corporate governance and its implications" (1999) 93 Northwestern University Law Review 641

"Racing towards the top?: The impact of cross-listings and stock market competition on international corporate governance" (2002) 102 Columbia Law Review 1757

Confederation of Indian Industry, Desirable Corporate Governance: A Code (1998)

Cunningham, C. D., "The world's most powerful court: Finding the roots of India's public interest litigation revolution in the Hussainara Khatoon prisoners 
case," in S.P. Sathe and S. Narayan (eds.), Liberty, Equality and Justice: Struggles for a New Social Order (Lucknow, India: Eastern Book Company, 2003)

Debroy, Bibek, "Some issues in law reform in India," in J.J. Dethier (ed.), Governance, Decentralization, and Reform in China, India and Russia (Boston MA: Kluwer, 2000)

Dehua, Tang (ed.), Qita Gongsi Zuzhi Xingshi Yu Gufen Hezuo Qiye Falu Shiwu (= Legal Treaties on Other Firms of Corporate Organization and the Stock Cooperative Enterprise) (1998)

Durnev, Artyom, and Kim, E. Han, "To steal or not to steal: Firm attributes, legal environment, and valuation" (2005) 60 Journal of Finance

Gilson, Ronald J., "Globalizing corporate governance: Convergence of form or function" (2001) 49 American Journal of Comparative Law

Goswami, Omkar, Corporate Bankruptcy in India: A Comparative Perspective, Development Centre Studies (Paris: OECD, 1996)

"India: The tide rises gradually," in Charles P. Oman (ed.), Corporate Governance in Development: The Experiences of Brazil, Chile, India, and South Africa (Issy-les-Moulineaux: OECD Development Center; Washington DC: Center for International Private Enterprise, 2003)

Government of India (1997), Report of Working Group on the Companies Act Green, Stephen Paul, China's Stock Market: A Guide to its Progress, Players and Prospects (London: Profile, 2003)

Hansmann, Henry and Kraakman, Reinier H., "The end of history for corporate law" (2001) 89 Georgetown Law Journal 439

Howson, Nicholas Calcina, "China's restructured commercial banks: The old nomenklatura system serving new corporate governance structures?" in M. Avery, M. Zhu and J. Cai (eds.), China's Emerging Financial Markets: Challenges and Global Impact (Singapore: John Wiley and Sons, 2009)

"The doctrine that dared not speak its name: Anglo-American fiduciary duties in China's 2005 company law and case law intimations of prior convergence," in H. Kanda, K. Kim and C. Milhaupt (eds.), Transforming Corporate Governance in East Asia (Abingdon: Routledge, 2008)

Huang, Yasheng, Selling China: Foreign Direct Investments During the Reform Era (Cambridge University Press, 2003)

Huang, Yasheng and Khanna, Tarun, "Can India overtake China?" (2003: July-August) Foreign Policy

Johnson, Simon, Peter Boone, Alasdair Breach, and Eric Friedman, "Corporate gov-" ernance in the Asian financial crisis" (2000) 58 Journal of Financial Economics

Joshi, Vijay and Little, I. M. D., India's Economic Reforms 1991-2001 (Oxford: Clarendon Press, 1996)

Khanna, Tarun and Krishna Palepu, "The evolution of concentrated ownership in India: Broad patterns and a history of the Indian software industry," in 
Randall K. Morck (ed.), A History of Corporate Governance around the World (University of Chicago Press, 2005)

"Is group affiliation profitable for in emerging markets? An analysis of diversified business groups" (2000) 55 Journal of Finance

"Policy shocks, market intermediaries, and corporate strategy: The evidence from Chile and India" (June 1999) 8(2) Journal of Economics \& Management Strategy 271-310

Khanna, Vikramaditya S., "Corporate crime legislation: A political economy analysis" (2004) 82(1) Washington University Law Quarterly

"Corporate governance in India: Past, present and future?" (2009) 1 Jindal Global Law Review

Kirby, William C., "China unincorporated: Company law and business enterprise in twentieth century China" (1995) 54(1) Journal of Asian Studies 43

Klapper, Leora F. and Love, Inessa, "Corporate governance, investor protection and performance in emerging markets" (2003) Journal of Corporate Finance, forthcoming, available at http://ssrn.com/abstract $=303979$

Krueger, Anne (ed.), Economic Policy Reforms and the Indian Economy (University of Chicago Press, 2002)

La Porta, Rafael, Florencio Lopez-de-Silanes, Andrei Shleifer, and Robert Vishny,

"Investor protection and corporate valuation" (2002) 57 Journal of Finance "Law and finance" (1998) 106 Journal of Political Economy

"Legal determinants of external finance" (1997) 52 Journal of Finance

"What works in securities laws" (2006) 61 Journal of Finance

Lardy, Nicholas R., China's Unfinished Economic Revolution (Washington DC: Brookings Institution Press, 1998)

Malegam, Shri Y.H., Report of the Sebi Committee on Disclosure Requirements in Offer Documents under the Chairmanship of Shri Y. H. Malegam (1995) Miles, James, "China Survey," The Economist (25 March 2006)

Mohan, R. and Aggrawal, V., "Commands and controls: Planning for industrial development in India, 1951-1990," (1990) 14 Journal of Comparative Economics 681

Morris, M.D., "The growth of large scale industry up to 1947," in D. Kumar (ed.), Cambridge Economic History of India, vol. II (Cambridge University Press, 1983), pp. 553-676

Murthy, Shri N. R. Narayana, Report of the Committee Appointed by the Sebi on Corporate Governance Under the Chairmanship of Shri N. R. Narayana Murthy (2003)

Naresh Chandra Committee, Report of the Naresh Chandra Committee on Corporate Audit and Governance (December 23, 2002)

Naresh Chandra Committee, Report of the Committee on Regulations of Private Companies and Partnership (Naresh Chandra Committee - II, July 31,2003$)$ 
Naughton, Barry, Growing Out of the Plan: Chinese Economic Reform 1978-1993 (Cambridge University Press, 1995)

Parekh, Shri Sandeep P., Report of the SEBI Sub-committee on Integrated Disclosures under the Chairmanship of Shri Sandeep P. Parekh (2008)

Peerenboom, Randall, China's Long March Toward Rule of Law (Cambridge University Press, 2002)

Peng, Jiusong, Zhongguo Qiyue Gufenshi (China's Contracting Stock System) (1994) Rajan, Raghuram G. and Luigi Zingales, "The great reversals: The politics of financial development in the twentieth century" (2003) 69 Journal of Financial Economics

Roe, Mark J., "Legal origins and stock markets in the twentieth century" (2006) 120(2) Harvard Law Review

Romano, Roberta, "The Sarbanes-Oxley Act and the making of quack corporate governance" (2005) 114(7) Yale Law Journal

Rungta, Radhe Shyam, The Rise of Business Corporations in India, 1851 - 1900 (Cambridge University Press, 1970)

Stout, Lynn, "Bad and not-so-bad arguments for shareholders primacy" (2002) 85 Southern California Law Review

Tenev, Stoyan and Zhang, Chunlin, with Brefort, Loup, Corporate Governance and Enterprise Reform in China: Building the Institutions of Modern Markets (Washington DC: World Bank; International Finance Corporation, 2002)

Thakurdas, Sir Purshotamdas, Tata, J. R. D., Birla, G. D., Dalal, Sir Ardeshir, Ram, Sir Shri, Lalbhai, Kastrubhai, Shroff, A. D. and Matthai, John, The "Bombay Plan" for India's Economic Development (Bombay: Printed by S. Ramu, at the Commercial Printing Press, 1944)

Thomas, Susan, "How the financial sector in India was reformed," in S. Narayan (ed.), Documenting Reforms: Case Studies from India (New Delhi: Macmillan, 2006)

Umarji, Madhukar R., "Trends and developments in insolvency systems and risk management: The experience of India," paper presented at OECD's Forum on Asian Insolvency Reform (2004)

World Bank, India: Role of Institutional Investors in the Corporate Governance of their Portfolio Companies, World Bank Report (2005)

World Bank, Doing Business in South Asia in 2007, country profile of India (2007) Xiang, Lanxin, Recasting the Imperial Far East: Britain and America in China, 1945-1950 (Armonk NY: M. E. Sharpe, 1995) 